\title{
BALBÍN'S DIVA MONTIS SANCTI (1665) AND ITS VERNACULAR VERSIONS AS A TYPE OF EARLY MODERN TRANSLATIONS*
}

\author{
ALENA BOČKOVÁ
}

\begin{abstract}
Diva Montis Sancti (1665), written by B. Balbín, is an important work on Marian pilgrimage sites. Within the background of the cultural and historical contexts, the paper compares the Latin text with its translation into Czech (Přepodivná Matka Svatohorská, 1666) by M. V. Štejer and an anonymous German version (Heiliger Berg, 1668). The language analysis of the Latin and Czech versions of the text is underpinned by examples of Štejer's translation strategies. The article also states the function and presumed readership of the versions. In contrast with the historical / patriotic function of the original aimed at educated European elites, both translations can be in today's terms characterised as paraphrases, accentuating the religious and educative functions and, therefore, intended for less educated readers.
\end{abstract}

Keywords: Diva Montis Sancti; Bohuslav Balbín; Přepodivná Matka Svatohorská; Matěj Václav Štejer; Heiliger Berg; Neo-Latin literature; Baroque translations; Marian pilgrimage sites; hagiographic literature

\section{Introduction}

In his conclusion to Dynamics of Neo-Latin and the Vernacular, Tom Deneire states three main research traditions in Early Modern multilingualism: "Imitatio / aemulatio", "Translation studies" and "Transfer studies". ${ }^{1}$ My article should be a contribution mainly to "Translation studies", 2 using the methodological approach that compares form, content

* This study was created with the financial support of the Czech Science Foundation as a part of standard project no. 17-19400S.

1 Deneire (2014c).

2 For an introductory overview see Hosington (2014); cf. also Ijsewijn, Sacré (1998: 488-501); Burke (2007a; 2007b); Deneire (2014b; 2014d); Bloemendal (2014; 2015); Čapská (2014); Ramminger (2015-2016); Pérez Fernández, Wilson-Lee (2014). An historical overview in the European context provide e.g. Windle, Pym (2011).

The core of Czech translation theories is formed by the work of Jiří Levý, closely followed by Anton Popovič: last edition Levý (2012); an English translation Levý (2011); Popovič (1975). Svoboda (2010) 
and linguistic aspects of the original and the translated text. The aim of such an analysis is to determine the extent to which the translation is exact or free and to state the function of the work depending on its source and target language. ${ }^{3}$ The study focuses on two translations of the Latin treatise Diva Montis Sancti, which are typical representatives of Baroque adaptations with extensive text changes.

Diva Montis Sancti, published in $1665,{ }^{4}$ is one of the most important works by the great Latinist Bohuslav Balbín and the culmination of his Marian hagiographic production. It was preceded by other Divae, works pertaining to Marian pilgrimage sites (Silesian place Warta Diva Wartensis and Moravian place Turany Diva Turzanensis). ${ }^{5}$ Following Diva Montis Sancti, Balbín utilised the same topic in the two final books of his historical treatise Epitome rerum Bohemicarum seu Historia Boleslaviensis. ${ }^{6}$ The religious place of the examined writing, Mons Sanctus (Svatá Hora), is located in the middle of Bohemia, adjacent to the formerly renowned mining town of Příbram. Only a year later, a Czech translation was published by the outstanding expert on Czech literary language Matěj Václav Štejer.7 The author of the translation is not listed on the title page, nevertheless Balbín himself attributes the translation to Štejer. Balbín mentions in his catalogue of scholars called Bohemia Docta that Štejer translated the history of Mons Sanctus from Latin to Czech and he characterises this translation as an abridged summary (historia in compendium contracta). ${ }^{8}$ The author of the German translation (Heiliger Berg), which was published two years later, remains unknown. ${ }^{9}$ However, the German version corresponds to the Czech version in its extent and structure ${ }^{10}$ and, thus, it is likely that the translator also used the Czech version when adapting the Latin original. ${ }^{11}$

deals with methodological approaches in the research of Baroque translations, focusing mainly on multilingualism in the Czech lands and relations between Latin, Czech and German works.

3 This approach is close to G. Toury's methodology for descriptive translation studies. In his theoretical framework oriented to target text, he combines a linguistic comparison of original and translated versions and the wider role of the sociocultural system. His aim is to identify the translation strategies and thereby to define the norms in the translation process. Cf. Munday (2016: 174-186).

${ }^{4}$ Balbinus (1665) - hereinafter Diva Montis Sancti. There are tens of copies preserved in Czech and foreign libraries as well; $\mathrm{cf}$. for instance the library search engine WorldCat: https://www.worldcat .org/search?qt=worldcat_org_all\&q=diva+montis+sancti (acc. March 31, 2020).

The 2nd edition: Balbinus (1670).

5 Balbinus $(1655 ; 1658)$.

6 Balbinus (1673).

7 Štejer (1666) - hereinafter Přepodivná Matka Svatohorská.

8 Balbinus (1778: 418 [s.v. ‘Štejer']): Item Historiam S. Montis in compendium contractam ex latino bohemice reddidit.

9 Heiliger Berg (1668) - hereinafter Heiliger Berg. Unfortunatelly, no research has been done about this treatise.

10 See the structure of all three versions in the attachment.

11 As a proof for this statement cf. e.g. the different titles of the chapter about Ernestus I. Archiepiscopus Pragensis (Diva Montis Sancti II, 6; Přepodivná Matka Svatohorská I, 5; Heiliger Berg I, 4) or the Relatio Ernesti (Přepodivná Matka Svatohorská part of I, 7; Heiliger Berg I, 7), missing in the Latin treatise and included in the Czech version with these words: Chceš-li pak věděti, laskavý čtenárí, kterak Arnošt, jsa ještě pacholetem, potrestán byl od dotčeného kladského Panny Marie obrazu, položím tuto (ač v latinské svatohorské historii se nenachází, ale v české léta 1655 na světlo vydané) předivné naddotčeného velebného otce Arnošta vidění, od něho samého před smrtí sepsané a k vyhlášení vydané [Kind reader, if you want to know how Ernestus, as a child, was punished by the Virgin Mary painting in Glatz, I will describe a vision of reverend Father Ernestus (not mentioned in the Latin history of Mons Sanctus but published in the Czech one in 1655), that was written by himself and issued before his death] (Přepodivná Matka Svatohorská, p. 35). Hereinafter, all Czech citations are translated by A. Bočková. 
The topic of the book Diva Montis Sancti has to be examined in a broader context of hagiographic works on the Marian theme and of literary production in Baroque Bohemia. The cult of the Virgin Mary had a unique position in the Czech lands in the 17th and 18th centuries. Pilgrimages to places dedicated to the Virgin Mary were one of the main expressions of Baroque religiousness and they took place wholly within the re-catholicisation intentions of the ruling Habsburg dynasty. A number of books were created that celebrate miraculous Marian depictions. Some of them were geographically divided registers, the most famous one was probably Atlas Marianus by Wilhelm Gumppenberg to which Bohuslav Balbín also contributed (namely to the issue from 1672). ${ }^{12}$ Others were dedicated to individual paintings / sculptures, for instance Divae of Justus Lipsius, ${ }^{13}$ which also served as an example for Balbín. These authors not only wanted to honour the Virgin Mary but also to have an educative impact on a broad range of readership since the books were published in multilingual versions (in bilingual Bohemia, besides Latin, usually also in Czech and German languages). ${ }^{14}$ The inner structure of the treatises did not differ much. In books dedicated to one specific pilgrimage site, an inscription and a foreword were usually followed by a legend about the origins of the place and its name, the history of the site and its surroundings and a description of the miraculous depiction. The major part of the book is then dedicated to miracles that subsequently happened.

Diva Montis Sancti represents the peak of this type of hagiographic literature dedicated to a single pilgrimage site. Its author, Jesuit Bohuslav Balbín (1621-1688), ${ }^{15}$ was appreciated by the Bohemian and European intellectual elites as an educator, poet, literary scholar, toponymist, hagiographer, historian and a staunch patriot. All of his books were written in Latin; the only Czech sentence (Saint Wenceslas' apostrophe: Nedej zahynouti nám i budoucím! [Don't let us and our posterity perish!]) concludes his treatise about the defence of the Czech language generally called Dissertatio apologetica. ${ }^{16}$ For his extensive historical work, Balbín was called the "Bohemian Livy". The translator of the Czech version, Jesuit Matěj Václav Štejer (1630-1692), ${ }^{17}$ was a teacher, preacher, missionary, translator of the New Testament and religious literature and an author of Czech treatises. He wrote inter alia a popular language handbook called Žáček (Pupil), ${ }^{18}$ which has summarised the standard language norm of that time. In the period 1664-1666, he resided at Svatá Hora where he probably met with Balbín several times. Unfortunately, there is no evidence as to whether they discussed the translation of Diva Montis Sancti together or not. At any rate, these two authors have created a very important work for Czech literary history, which also illustrates the social situation and the state of religiousness in Baroque Bohemia. The main part of this article constitutes a comparison of the language variations of the treatise.

12 Gumppenberg (1672).

13 Lipsius $(1604 ; 1605)$.

14 Svatoš (2000).

15 Cf. Sommervogel (1890: 792-808); Bobek (1931); Kalista (1939); Kučera, Rak (1983); Rejzek (1908); Pokorná, Svatoš (1992).

16 Balbinus (1775).

17 Cf. Sommervogel (1896: 1575-1577); Stich (2001); Svatoš (2001); Kroupa (1994); Koupil (2012).

18 Štejer (1668). 


\section{Diva Montis Sancti vs. vernacular versions}

\section{Form of the book}

The Latin treatise is almost twice as long as the vernacular versions. When translating Balbín's original, the translators adjusted it greatly; they left out many historical and geographical passages, sometimes even whole sections or chapters, and concentrated mainly on the miracles. The vernacular versions of the treatise have therefore predominantly religious character. A different format and number of pages show that both the Czech and German versions are almost half the size, the German even smaller, ${ }^{19}$ and thanks to it, readers could probably keep it at hand and carry it with them during their pilgrimages to Svatá Hora to remind them of the miracles right on the spot.

All three versions contain engravings depicting the statue of Sacromontana Virgin Mary although in a different illustration, according to the printing block available in the printing house. An interesting observation was made with other engravings in the Latin and Czech treatises, namely about the sanctuary. Although both versions were published only one year apart, in the Latin version the church at Svatá Hora is depicted in its original form as a small chapel, whereas in the Czech version it is depicted in its current form as a large Baroque church, resulting from a reconstruction led by Carlo Lurago. This latter engraving is probably one of the newest depictions, most likely based on architectural plans than on the actual appearance of the Svatá Hora complex. Work on the extensive reconstruction was taking place at the time when both books were written, namely in the period 1659-1673.

In terms of the typographic layout of the books, the Latin core text is accompanied by frequent marginalia. Through them Balbín supplies links, divides the text into subchapters, numbers individual events, gives explanations, adds Czech names or summarises the paragraph content. These and other formal adjustments ensure better orientation in the text. In both translations, marginalia are omitted, the text is rarely divided into paragraphs and the abridged text is thus difficult to navigate through. The reasoning for this was probably the author's or printer's attempt to save space. In the marginalia, Balbín also lists sources of his quotes from classical authors, the Bible, medieval authorities and contemporary writers, which he uses in the text as examples, parallels or as a basis for reflections. The translators do not list the sources, not even in the plain text; moreover they often exclude the reflections entirely. This could have resulted from the assumption that these quotations and reflections neither add to the main story line, nor pertain directly to the miracles, and, thus, they might distract the readers from the principal topic.

The Latin text is accompanied by verses, in the form of both short and longer epigrams, which conclude almost every chapter. Their topics are a celebration of the Virgin Mary and her mercifulness, the flourishing of Svatá Hora, devotional praise or poetic plays. ${ }^{20}$ However, not all of them are necessarily written by Balbín. ${ }^{21}$ All these epigrams

19 Diva Montis Sancti: format $4^{\circ}$, size $15 \times 19 \mathrm{~cm}, 618$ pp; Přepodivná Matka Svatohorská: format $8^{\circ}$, size $9 \times 15 \mathrm{~cm}, 510 \mathrm{pp}$, Heiliger Berg: format $8^{\circ}$, size $10 \times 15 \mathrm{~cm}, 396 \mathrm{pp}$.

20 For instance a poem addressed to the pen describing miracles of the Virgin Mary Ad pennam scriptoriam, ut sese ad miracula Beatissimae Matris scribenda comparet diligenter (Diva Montis Sancti, p. 4-5).

21 E.g. Praecatio poetae ad Divam Sacromontanam pro patria (Diva Montis Sancti, p. 136-137), which Balbín introduces: Addam hoc loco, forsitan opportune ad oblectandum lectorem, pro patria preces expressas carmine, quas discipulus meus et religionis instituto frater, cum S. Montem una conscender- 
are omitted in both the Czech and German texts; nevertheless the German translator adds other verses / Marian litanies at the end of each book, in order to create a more compact hagiographic work. ${ }^{22}$

\section{Structure and content}

As a typical foreword, all versions use a dedication, the traditional form for expressing honour and thanks to the donors, which were different for each book version. ${ }^{23}$ In the Latin Epistola dedicatoria, Balbín additionally includes historical comments or reflections on the dedication genre and outlines how he has divided the entire work (origines et miracula). The German version inserts only a short conventional dedication (2 pages). The Czech translation attaches after its dedication a foreword to reader, concluded by an important note in which Štejer formulates the main principles of his translation method - paraphrased from Czech he says: “The translator of this History wanted it to be well understood by common people. Hence he intentionally omitted verses and other means of high style and, where necessary, added explanations for the readers."24

The text of the original is divided into five books (libri). In the first two (called origines), Balbín narrates the history of Svatá Hora, its miraculous statuettes, describes the Svatá Hora's complex, chapel, hermitage and healing spring, as well as the town of Př́bram and its surroundings. He depicts legends and the most important historic events and he describes at length the silver mines, including such details as a description of a machine used for draining the water from the mines. ${ }^{25}$ The first book - which consists of general considerations of miracles, holy sites, the meaning of pilgrimages and of worshipping miraculous statuettes - was not included in the translations. From the second book, the vernacular versions left out everything that was not closely connected to Svatá Hora (details about the town of Př́bram, silver mines, mining machinery etc.). The German translator only inserted a brief summary of the history of the town Pŕíbram as an introduction to the whole book. ${ }^{26}$

The next three books are dedicated to the miracles of the Virgin Mary (miracula) and - as a pendant - followed by benefactions of grateful believers: devotional offerings, precious gifts for Svatá Hora, financed constructions and works of art. The miracles are thematically divided: transformations of the statuette (tears, sweat or blood announcing future disasters), light and sound phenomena (rays around the chapel, bells tolling on

emus, Beatissima Virgine adorata, in Sylvulae modum effudit ex tempore mihique adhuc ab ingenio calens et rubens porrexit. (Diva Montis Sancti, p. 135).

22 Die Lauretanische Litanei (Heiliger Berg, p. 74-76), Ehren-Sonnet (Heiliger Berg, p. 187-188), poem O Du Mutter (Heiliger Berg, p. 300), poem Beschluß (Heiliger Berg, p. 396).

23 Diva Montis Sancti: Malovecz stirps; Přepodivná Matka Svatohorská: Aleš Ferdinand Vratislav z Mitrovic; Heiliger Berg: Frantz Edmund Putz von Adlers-Thurn.

${ }_{24}$ Co se pak dotejče prèeložení této Historie z latinské rečci na česko, věděti máš, laskavý čtenář́i, že kdo tuto Historii překládal, měl oumysl tak ji spraviti, aby sprosten lid mohl jí dobře rozuměti. A protož verše i jiné všecky vysoké a od skladatele latinské Historie di̊vtipně složené věci schválně opustil a mistem, kde se zdálo, že by sprosten lid potřeboval nějakého vysvětlení, něco přiložil. (Přepodivná Matka Svatohorská, p. A8v).

25 Diva Montis Sancti II, 3, $\$ 5$ (De artificiosa machina et automate, quo ex fodinis ad S. Montem aqua mirabiliter extrahitur et exantlatur). At the end of the chapter see the scheme Delineatio machinae, qua ex fodinis Przibramensibus aqua educitur (Diva Montis Sancti, engraving following page 96).

26 Heiliger Berg I, 1 partly translated from Diva Montis Sancti II, 2. 
their own) and miraculous healings of various diseases. Balbín always consistently lists his sources in order to put a stamp of historic work on his treatise. In these books, the translations deviate from the original to a much lesser extent. The translators leave out some quotations, philosophical and reflective passages or Latin and Greek verses. However, they never shorten the text to the detriment of the story; in some passages they even broaden it, correct information that is no longer up-to-date or add new pieces of information. ${ }^{27}$

In the epilogue, the Czech translator skips over Balbín's extensive digression into the topic of classical heroes and he connects only the introduction and the conclusion about the never ending mercifulness of the Virgin Mary. The Beschlu $\beta$ of the German translation consists only of few verses invocating the Holy Mother, ${ }^{28}$ which finally conclude the last chapter.

The next two appendices of the Latin treatise (topographic and genealogical) are left out in the vernacular versions, certainly for the reason that they deviate too much from the hagiographic topic and miracles. Nevertheless, the Czech translation adds as an attachment a discourse of Georgius Crugerius about the affection of the Virgin Mary towards the Czech people and, vice versa, the affection of the Czech people for the Virgin Mary, ${ }^{29}$ which is originally inserted in the first book of Diva Montis Sancti. ${ }^{30}$ Although this discourse does not relate to Svatá Hora and the miracles themselves, it can represent an appropriate conclusion of the whole book.

\section{Language and style}

In the Latin original, there are prevailing language-stylistic elements of humanistic Latin typical for Bohemia of the 17th and 18th centuries - so called "Baroque humanism". 31 The Czech text uses a good standard of Baroque language norms, reasoned from the fact that Štejer was not only a translator but also an author of several language handbooks. Our linguistic analysis was concentrated only on the Latin and Czech texts ${ }^{32}$ and compared both the lowest text units (words and terms), set phrases and constructions, as well as entire clauses, sentences and more extensive passages.

Štejer translated the Latin original rather freely, i.e. he focused mainly on the narrative of the text, which he transformed into a simple and easy-to-understand manner. We have listed some examples to show his translation approach to the text:

27 As already mentioned Relatio Ernesti: see above n. 11.

28 Heiliger Berg, p. 396.

29 Přepodivná Matka Svatohorská, p. 450-580 ('Přídavek'), where Štejer introduces: Ačkoli tato věc, o které chci nyní jednati, neprináleži vlastně k Svatohorské Historii, nicméně poněvadž jest k pochvale predešlé pobožnosti českého národu a müže býti podnětem k budoucí horlivosti a ctihodný Pater Jiří Crugerius z Tovaryšstva Ježíšova, an tuto částku složil, hoden jest, aby tato jeho perlička z onoho Pokladu české pobožnosti, který míní světu ukázati, vzatá vyšla na světlo, soudím užitečnou věc býti, tuto jeho spis z latinska na česko přeložený připsati [Although this aspect, I want to present now, does not really belong to the History of Mons Sanctus, yet it praises the previous piousness of the Czech nation and may be an impetus for future zeal. Reverend Father Georgius Crugerius of the Society of Jesus composed this treatise as a pearl in the treasure of Czech devotion and it is worth being taken into the light and shown to the world. So I intend to attach here his text translated from Latin to Czech] (Přepodivná Matka Svatohorská, p. 450).

30 Diva Montis Sancti I, 9.

31 Hejnic (1974); Svatoš (2000).

32 A detailed analysis of the German translation is a task for future research. 


\section{Omissions}

The translator leaves out rhetorical adornments, especially these forming whole sentences, omits additional information or rhetorical questions. He skips historical or literary digressions, simplifies long clauses and searches for suitable phrases that allow him to substitute an entire sentence while preserving the substance of the original. This may be explained by the assumption that uneducated recipients will perceive the text only by listening.

- Leaving out rhetorical adornments:

Enimvero, ut haec ita sint, tamen veritatis ego exercitum contra statuam, armatura tam firma, ut immortales Persarum

Postavím proti nèmu pravdu v pevném odèní a s bystrou výbornou zbraní. ${ }^{34}$ (quos vocabant) milites non desideres ${ }^{33}$

ante genam per dies aliquot pendebat, několik dní nad lící viselo ${ }^{36}$ cruento chamaeleontis exemplo, quod animal oculos habet sanguine semper natantes $^{35}$

- Omitting additional information or rhetorical questions:

cum serenissimo coelo, in Augusto sub Virgine, cum formosissimus annus est 37

in media Germania natus, qui ut fit in artibus, quo eum error et libido rapiebat, peregrinabatur et magistris operam addicebat suam 39

hunc unum afflavit primum et obcoecavit, deinde dejecit exanimem. Haeccine est meretricis aut latronis potestas? ${ }^{41}$ ač bylo všudy na nebi jasno ${ }^{38}$ rodem $z$ Němec, člověk vandrovní 40

toho samého zlolejce trefil, omračil a na zem porazil ${ }^{42}$

33 Diva Montis Sancti, p. 245.

34 Přepodivná Matka Svatohorská, p. 164: "I will set the truth against him, in solid armour and with the best sharp weapon".

35 Diva Montis Sancti, p. 313.

36 Přepodivná Matka Svatohorská, p. 246-247: "it hung for several days on her cheek”.

37 Diva Montis Sancti, p. 164.

38 Přepodivná Matka Svatohorská, p. 70: “even though all the sky was clear”.

39 Diva Montis Sancti, p. 163.

40 Přepodivná Matka Svatohorská, p. 68: "born in Germany and a wandering man”.

41 Diva Montis Sancti, p. 164.

42 Přepodivná Matka Svatohorská, p. 70: “it struck the only villain, stunned him and knocked him to the ground". 
- Skipping literary digressions:

secum adducit. Apparuit hic, quod scripsit Aristoteles: „Opus suum omnis Dovedši pak ji předce na to svaté místo ${ }^{44}$ bonus artifex diligit." $" 3$

- Simplifying long clauses:

Is cum magnum operae suae pretium, totius fere Przibrami ad religionem ten skưro celé město na katolickou víru obrátiv ${ }^{46}$ nostram accessionem tulisset, Przibramensibus in fide notra satis jam confirmatis ${ }^{45}$

- Simplifying Latin synonymic variations (e.g. Latin synonyms imago, effigies, statua, signum translated with the only Czech word obraz [picture]).

\section{Shifts}

Štejer transposes the Latin phrases into the local environment, substitutes sayings or similes with Czech idioms and uses expressive elements or common and vulgar expressions.

imagines odissent et velut in ulcere a svatí obrazové byli jim jako sůl v očích ${ }^{48}$ unguem haberent ${ }^{47}$

\section{Additions}

On the other hand, he inserts explanations or repeats certain information in order to facilitate understanding. He amplifies the story for the sake of better continuity, fluency and clarity. In some places, he inserts his own reflections, ideas or observations into the text, as well as effective metaphors, similes or poetical ornaments, which adds interest to the translation and makes it more gripping for the readers.

- Inserting explanations:

Recte scripsit Seneca ${ }^{49}$

Poznamenal světský mudřec Seneka $a^{50}$

${ }^{43}$ Diva Montis Sancti, p. 315.

44 Přepodivná Matka Svatohorská, p. 250: "Then he led her to the holy place".

45 Diva Montis Sancti, p. 162.

46 Přepodivná Matka Svatohorská, p. 68: "he turned almost the entire city to the Catholic faith".

47 Diva Montis Sancti, p. 120.

48 Přepodivná Matka Svatohorská, p. 22: "and holy images were like salt in their eyes".

49 Diva Montis Sancti, p. 164.

50 Přepodivná Matka Svatohorská, p. 69-70: “The secular scholar Seneca noted”. 
- Amplifying the story:

Facit $^{51}$

ut ferre lucem sine horrore non posset ${ }^{53}$

Mors tibi, mors, sceleste, constituta fuit, nisi natura et mores coelestes vetarent: cum iratus fuerit Deus, misericordiae recordabitur ${ }^{55}$

\author{
Následujíc ona této dobré rady, \\ šla na Svatou Horu, tam svou pobožnost \\ vykonala ${ }^{52}$
}

že bez bolesti na žádné světlo nemohla hledèti, ale pro uvarování bolesti do tmavých koutưv, kde jen mohla, se ukrejvala ${ }^{54}$

Zasloužilt’ovšem ten Boha prázdný
člověk hned na tom místě od tohoto ohně
zcepenéti, ale milosrdný a dlouho
shovívající Bưh, bez pochyby na př́mluvu
Matky Milosrdenství, naložil s ním ne
podle zasloužení jeho, ale podle
milosrdenství svého, nechtě, aby zahynul 56

- Inserting own reflections:

horret calamus scribere! 57

Hrozím se jeho bezbožné klení vejslovně tuto poznamenati a bojím se, abych snad tím Pána Boha neurazil, kdybych je napsal; 58

sed invidia, cum maxime videt, Ale závistivý člověk vida nevidí, slyše nenil videt ${ }^{59}$ slyší, a proto mluví ledacos, byt toho nikdy nemohl prokázati. ${ }^{60}$

51 Diva Montis Sancti, p. 314.

52 Přepodivná Matka Svatohorská, p. 249: "she obeyed this good advice, went to Svatá Hora and there did her devotion".

53 Diva Montis Sancti, p. 314.

54 Přepodivná Matka Svatohorská, p. 249: "that she couldn’t look at any light without pain, but to hide from pain, she hid in the dark corners wherever possible".

55 Diva Montis Sancti, p. 164.

56 Prepodivná Matka Svatohorská, p. 70: "Surely the impious man deserved to be killed by the fire, right in that place, nevertheless without doubt at the intercession of the Mother of Mercy, the merciful and long-forgiving God dealt with him not according to villain's merits but according to his own mercy, because he did not want him to perish.

57 Diva Montis Sancti, p. 163.

58 Přepodivná Matka Svatohorská, p. 69: "I fear to explicitly mention his blasphemous curse and I am afraid I might offend God if I wrote it".

59 Diva Montis Sancti, p. 244-245.

60 Přepodivná Matka Svatohorská, p. 164: "But an envious person, though he sees, does not see, though he hears, does not hear, and, therefore, speaks many things, even if he could never prove it". 
respondit, tam acutum jam esse, quam sit calumnia ${ }^{61}$
Odpověděl, že jest tak ostrý jako pohanèní. Nad pohanění pak není ostřejšího meče na světě. Tímt' zajisté všecko se může přetiti, všecko poraziti. Nebo nic není tak svatého, tak jistého, tak dokonalého, čeho by člověk nemohl pohaněti. ${ }^{62}$

- Adding poetical adornments:

sua Matri Dei veneratio et affectus in eam tot saeculis intermortuus coepit exsurgere 63

At sceleratus nebulo in domum Joannis Welwarsky ingressus ${ }^{65}$ povstala jako z mrtvých někdejší česká k Matce Boží láska a zdálo se všem katolíkưm, jako by nastalo žádoucí a milé jaro po dlouhé a tuhé zimé. ${ }^{64}$

ale bylo to platno, jako kdyby někdo hrách na stènu sypal, neb prijida s tím rouháním do hospody 66

The Czech word order often remains influenced by the Latin (for instance a verb at the end, hyperbaton ${ }^{67}$ or postposition of adjectives) and, following the Latin example, the Czech text is divided by rhetorical punctuation. The translator uses many participles ${ }^{68}$ as a means of condensing the text and even infinitive phrases can be found, which is untypical for the Czech language. ${ }^{69}$

On the contrary, the Latin text is retrospectively influenced by Czech, which is a quite uncommon aspect. There are, for example, Czech toponyms, explanations or allusions in the marginalia. Perhaps most interesting is a linguistic pun pertaining to the name of the Czech hermit called Procházka (whose name means a "walk" in Czech) in a short epigram:

Prochazkam nostris fecit Prochazka Bohemis;

Virginis ad Montem Patria tota venit.

61 Diva Montis Sancti, p. 245.

62 Přepodivná Matka Svatohorská, p. 164: "He replied that it was as sharp as the calumny. There is no sharper sword in the world than the calumny. It can cut everything, defeat everything. For nothing is so holy, so certain, so perfect, that one cannot defame it".

63 Diva Montis Sancti, p. 162.

64 Přepodivná Matka Svatohorská, p. 67: "the former Czech love for the Mother of God arose like from the dead, and it seemed to all Catholics as if a desirable and sweet spring had occurred after a long and stiff winter".

65 Diva Montis Sancti, p. 163.

66 Přepodivná Matka Svatohorská, p. 69: "but it was like throwing peas on the wall, for when he came to the pub with the blasphemy".

67 Někdejší česká k Matce Boží láska; za jeden rok našeho na Svaté Hoře přisluhování; výborný prírodních věcí zpytatel.

68 došedši, obrátiv, následujíc, nechtě, přijda...

69 Odpověděl se s př́sahou několikrát opětovanou do své nejdelší smrti nic více proti Rodičce Boží nemluviti ani činiti. Soudím užitečnou věc býti... 
Balbín explains the meaning of this name to readers without the command of Czech in his marginalia: Prochazka Boëmice, Latine Ambulatio. ${ }^{70}$

\section{Conclusion}

From the formal part of the comparison above it follows that the vernacular versions of the treatise cannot be considered as translations within today's meaning of the word. They present a selection, i.e. a paraphrase / adaptation, ${ }^{71}$ done with a different intention and for a different readership than the Latin original. In the Latin work, the ratios between hagiographic elements and other parts, mainly historic, topographic and genealogical, is balanced, whereas the translations focus purely on the miracles because they offer faith in healing, mercifulness and the protection of the Virgin Mary to common readers. This is the reason why all digressions, philosophical, historic and patriotic passages, as well as verses and rhetorical adornments, are left out in the translations.

The languages of the different versions also refer to the intended recipients. Balbín's book is comprehensible only to a reader who commands Latin and who is capable of appreciating the author's style of narration, which involves long digressions, expert descriptions, quotations from Greek and Latin works, and a high stylistic level of text. This treatise was intended for the educated European elites and, besides a promotion of the Cult of the Virgin Mary, it has informative, historical-educational and patriotic functions, not overlooking its aesthetic function as well.

The Czech and German vernacular versions, on the other hand, make the text accessible for local readers or listeners. The translations are abridged with respect to the content and the topic of the original and omit large parts of the text. They leave out not only the quotes by classical authors but also a number of biblical quotes or parallels and thus significantly shift Balbín's style of narration. In the translations, the religious experiences result mainly from miracles, cult objects and acts. However, the detailed language analysis of the Czech translation shows Štejer's deep understanding of the original and a great feeling for the language. He avoids literal set phrases, yet interprets faithfully the essence and the meaning of the story. He transposes the Latin text with the same richness and aptness, adds plasticity to the text through his own complements and uses Baroque figurativeness, all of which are necessary elements for capturing the attention of common readers. The function of both translations is especially religious-educative and they are primarily intended for lower social classes.

This submitted article will hopefully serve as a component for a larger synthesis of the typology of Baroque translations in the Czech lands during the 17th and 18th century. Such a summary outline cannot be done without primary form, content and linguistic comparisons of the originals and the translations, which determine the function of the works and their intended readership. Further work is needed to draw up a comprehensive list and classification of the translation output. These pebbles in the mosaic will finally help to create a picture of Early Modern multilingual dynamics.

70 Diva Montis Sancti, p. 225.

71 In modern translation theory, these terms are defined as degrees of free translation. Cf. Hrehovčík (2006); Bastin (2020). 


\section{REFERENCES}

\section{Printed sources}

Balbinus, B., 1655. Diva Wartensis seu Origines et miracula magnae Dei hominumque Matris Mariae, quae a tot retro saeculis Wartae, in limitibus Silesiae Comitatusque Glacensis, magna populorum frequentia colitur, clarissima miraculis. Pragae: Caesareo-Academica typographia.

Balbinus, B., 1658. Diva Turzanensis seu Historia originis et miraculorum magnae Dei hominumque Matris Mariae, cujus venerabilis satuta, prope Burnam indicio coelestis lucis in rubis inventa, magno populorum accursu honoratur. Olomutii: V. H. Ettelus.

Balbinus, B., 1665. Diva Montis Sancti seu Origines et miracula magnae Dei hominumque Matris Mariae, quae in Sancto Monte regni Bohemiae ad argentifodinas Przibramenses quotidiana populi frequentia et pietate in statua sua mirabili aditur et colitur. Pragae: G. Czernoch.

Balbinus, B., 1670. Diva Montis Sancti seu Origines et miracula magnae Dei hominumque Matris Mariae, quae in Sancto Monte regni Bohemiae ad argentifodinas Przibramenses quotidiana populi frequentia et pietate in statua sua mirabili aditur et colitur. Pragae: G. Czernoch.

Balbinus, B., 1673. Epitomes rerum Bohemicarum seu Historiae Boleslaviensis libri duo: VI. et VII., quorum prior gloriam antiquissimae collegialis ecclesiae Vetero-Boleslaviensis, alter origines et gratias coelestes gloriosae Dei Matris Mariae, quae ibidem Vetero-Boleslaviae ab annis propemodum DCCC colitur, comprehendit. Pragae: Universitas Carolo-Ferdinandea.

Balbinus, B., 1775. Dissertatio apologetica pro lingua Slavonica, praecipue Bohemica. Opus postumum. Ed. F. M. Pelcl. Pragae: F. Mangold.

Balbinus, B., 1778. Bohemia docta. Pars 2. Ed. R. Ungar. Pragae: M. Glatz.

Gumppenberg, G., 1672. Atlas Marianus, quo Sanctae Dei Genitricis Mariae imaginum miraculosarum origines duodecim historiarum centuriis explicantur. Monachii: J. Jaeklinus.

Heiliger Berg, 1668. Heiliger Berg oder Ausführliche Beschreibung des Wunderthätigen Bildnuß Unser Lieben Frauen ob dem Heiligen Berg im Königreich Böheimb. Von wem dasselbige seinen Ursprung? Und mit was ansehlichen Wunderzeichen es bießhero geleuchtet habe? Gezogen aus dem lateinischen Ursprungs- und Geschichtbuch des Ehrwürdigen Patris Bohuslai Balbini der Societät Jesu Priesters. Prag: P. Tuchscherer.

Lipsius, J., 1604. Diva Virgo Hallensis, beneficia eius et miracula fide atque ordine descripta. Antverpiae: J. Moretus.

Lipsius, J., 1605. Diva Sichemiensis sive Aspricollis, nova eius beneficia et admiranda. Antverpiae: J. Moretus.

[Štejer, M. V.], 1666. Přepodivná Matka Svatohorská Maria v zázracích a milostech svých na Hoře Svaté nad městem Př́bramí hor stříbrných den po dni víc a víc se skvějicí; z latinské historie skrz ctihodného kněze Bohuslava Balbina z Tovaryšstva Ježíšova sepsané vybraná, v češtinu od jednoho z téhož Tovaryšstva pátera préeložená [Divine Mary Mother of Svatá Hora, in her miracles and graces on the Svatá Hora, which is shining day after day above the silver mining town of Pribram; from a Latin history, written by the venerable priest Bohuslav Balbin of the Society of Jesus, selected and translated into Czech by one Father of the same Society]. Litomyšl: J. Arnolt.

Štejer, M. V., 1668. Výborně dobrý způsob, jak se má dobře po česku psáti neb tisknouti [An excellent way how to write or print in Czech]. Praha: Universitas, Kolej Soc. Jesu.

\section{Secondary sources}

Bastin, G. L., 2020. 'Adaptation'. In: M. Baker, G. Saldanha (eds.), Routledge Encyclopedia of Translation Studies. 3rd ed. London / New York: Routledge, 10-14.

Bloemendal, J., 2014. 'Introduction: Dynamics of Neo-Latin and the Vernacular: Some Thoughts Regarding Its Approach' In: Deneire (2014a: 18-29).

Bloemendal, J., 2015. 'Introduction: Bilingualism, Multilingualism and the Formation of Europe'. In: J. Bloemendal (ed.), Bilingual Europe. Latin and Vernacular Cultures, Examples of Bilingualism and Multilingualism c. 1300-1800. Leiden: Brill, 1-14.

Bobek, W., 1931. 'Úloha kultu mariánského v dějepisecké tvorbě Balbínově' [The role of the Marian cult in the historical writings of Balbín]. Sborník Matice slovenskej pre jazykospyt, národopis, dejepis a literárnu historiu $9,142-154$. 
Burke, P., 2007a. 'Cultures of Translation in Early Modern Europe'. In: Burke, Hsia (2007: 7-38).

Burke, P., 2007b. 'Translations into Latin in Early Modern Europe'. In: Burke, Hsia (2007: 65-80).

Burke, P., Hsia, R. P. (eds.), Cultural Translation in Early Modern Europe. Cambridge: Cambridge University Press.

Čapská, V., 2014. 'Cultural Transfers by Means of Translation. Bohemian Lands as a Space of Translation Flows During the Seventeenth and Eighteenth Centuries'. In: V. Čapská, R. Antonín, M. Čapský (eds.), Processes of Cultural Exchange in Central Europe, 1200-1800. [Praha]: European Social Fund / Opava: Silesian University, 77-127.

Deneire, T. (ed.), 2014a. Dynamics of Neo-Latin and the Vernacular. Leiden: Brill.

Deneire, T., 2014b. 'Introduction: Dynamics of Neo-Latin and the Vernacular: History and Introduction'. In: Deneire (2014a: 1-17).

Deneire, T., 2014c. 'Conclusion: Methodology in Early Modern Multilingualism'. In: Deneire (2014a: 302-314).

Deneire, T., 2014d. 'Neo-Latin and the Vernacular: Methodological Issues'. In: Ford, Bloemendal, Fantazzi (2014: 275-285).

Ford, Ph., Bloemendal, J., Fantazzi, Ch. (eds.), 2014. Brill's Encyclopaedia of the Neo-Latin World. Leiden / Boston: Brill.

Hejnic, J., 1974. 'Balbínova cesta za antikou' [Balbin’s journey to antiquity]. Listy filologické 97, 217-234.

Hosington, B. M., 2014. 'Translation and Neo-Latin'. In: Ford, Bloemendal, Fantazzi (2014: 127-139).

Hrehovčík, T., 2006. Prekladatel'ské minimum [A basic guide to translation]. Bratislava: Iris.

Ijsewijn, J., Sacré, D., 1998. Companion to Neo-Latin Studies 2. Literary, Linguistic, Philological and Editorial Questions. 2nd ed. Leuven: Leuven University Press.

Kalista, Z., 1939. Bohuslav Balbín. Praha: Fr. Borový.

Koupil, O., 2012. Jezuité Drachovius a Steyer, Gramatiky češtiny [The Jesuits Drachovius and Steyer, Czech grammars]. Praha: KLP.

Kroupa, J. K., 1994. 'M. W. Stejer v zrcadle Catalogi triennales II' [M. W. Stejer in a mirror of Catalogi triennales II]. Listy filologické 117, 316-318.

Kučera, J. P., Rak, J., 1983. Bohuslav Balbín a jeho místo v české kultuře [Bohuslav Balbín and his place in Czech culture]. Praha: Vyšehrad.

Levý, J., 2011. The art of translation. Transl. by P. Corness. Ed. with a critical foreword by Z. Jettmarová. Amsterdam / Philadelphia: John Benjamins Publishing Company.

Levý, J., 2012. Umění překladu [The art of translation]. 4th ed. Praha: Apostrof.

Munday, J., 2016. Introducing translation studies: Theories and Applications. 4th ed. London: Routledge.

Nečas, D., 2001. M. V. Štejer, Žáček aneb Výborně dobrý zpưsob, jak se má dobře po česku psáti neb tisknouti. [Ed. by D. Nečas.] Praha: Akropolis.

Pérez Fernández, J., Wilson-Lee, E. (eds.), 2014. Translation and the Book Trade in Early Modern Europe. Cambridge: Cambridge University Press.

Pokorná, Z., Svatoš, M. (eds.), 1992. Bohuslav Balbín a kultura jeho doby v Čechách [Bohuslav Balbín and the culture of his time in Bohemia]. Praha: Památník národního písemnictví.

Popovič, A., 1975. Teória umeleckého prekladu [Theory of literary translation]. 2nd ed. Bratislava: Tatran.

Ramminger, J., 2015-2016. 'Language Change in Humanist Latin: the case of traducere (to translate)'. Analecta Romana Instituti Danici 40-41, 35-62.

Rejzek, A., 1908. P. Bohuslav Balbín T.J. Jeho život a práce [P. Bohuslav Balbín S.J.: His life and work]. Praha: Dědictví sv. Prokopa.

Sommervogel, C., 1890. Bibliothèque de la Compagnie de Jésus. Bibliographie. Tome I. Bruxelles: O. Schepens. Sommervogel, C., 1896. Bibliothèque de la Compagnie de Jésus. Bibliographie. Tome VII. Bruxelles: O. Schepens.

Stich, A., 2001. 'Štejerův Žáček a jeho kulturní poslání' [Štejer’s Pupil and his cultural mission]. In: Nečas (2001: VII-XX).

Svatoš, M., 2000. 'Zur Mehrsprachigkeit der Literatur in den böhmischen Ländern des 17. und 18. Jahrhunderts'. Wiener Slavistisches Jahrbuch 46, 33-42.

Svatoš, M., 2001. 'Osobnost, život a dílo Matěje Václava Štejera T. J. v podání jezuitských pramenů' [The personality, life and work of Matěj Václav Štejer S.J., as referred to in Jesuit sources]. In: Nečas (2001: CLI-CLXXVI). 
Svoboda, T., 2010. 'Metodologické implikace pro zkoumání barokního období v dějinách překladu’ [On research methodology concerning the Baroque period in translation history]. In: M. Janečková [et al.], Slovesné baroko ve stréedoevropském prostoru [Literary Baroque in the Central European territory]. Praha: ARSCI, 186-201.

Windle, K., Pym, A. 2011. 'European Thinking on Secular Translation'. In: K. Malmkjær, K. Windle (eds.), The Oxford Handbook of Translation Studies. Oxford: Oxford University Press, 21-30.

\title{
BALBÍNOVA DIVA MONTIS SANCTI (1665) A JEJÍ PŘEVODY DO NÁRODNÍCH JAZYKŮ JAKO JEDEN Z TYPŮ BAROKNÍCH PŘEKLADŮ
}

Jedním z metodologických prrístupů $\mathrm{k}$ analýze překladu je formální, obsahové a jazykové srovnání $\mathrm{s}$ originálem, stanovení míry volnosti či přesnosti překladu a zkoumání funkce díla v závislosti na jeho původním a cílovém jazyce. Tento článek se zaměřuje na překlad bohemikálního spisu Diva Montis Sancti (1665), který je typickým zástupcem barokních adaptací s rozsáhlými textovými úpravami a současně je jednou z nejvýznamnějších prací Bohuslava Balbína o mariánských poutních místech. Na pozadí kulturněhistorického kontextu a zařazení do dobové produkce v rámci tohoto žánru studie přináší komparaci latinského textu s jeho českým překladem od Matěje Václava Štejera (Přepodivná Matka Svatohorská, 1666) a s německou variantou (Heiliger Berg, 1668), jejíž autor zatím není znám. Podrobnější jazykovou analýzu latinské a české verze textu doplňují prríklady, demonstrující Štejerovy překladatelské postupy. Článek naznačuje, jaká byla funkce a předpokládaný recipient jednotlivých jazykových verzí: oba překlady lze charakterizovat jako parafráze, adresované méně vzdělanému čtenáři, akcentující nábožensky-vzdělávací funkci, na rozdíl od historicko-vlastenecké funkce originálu, který byl určen vzdělanecké elitě celé Evropy. Cílem studie je nastínit základní překladatelské tendence, a přispět tak k rozsáhlejšímu výzkumu typologie barokních překladů.

\author{
Alena Bočková \\ Charles University, Prague \\ alena.bockova@ff.cuni.cz
}




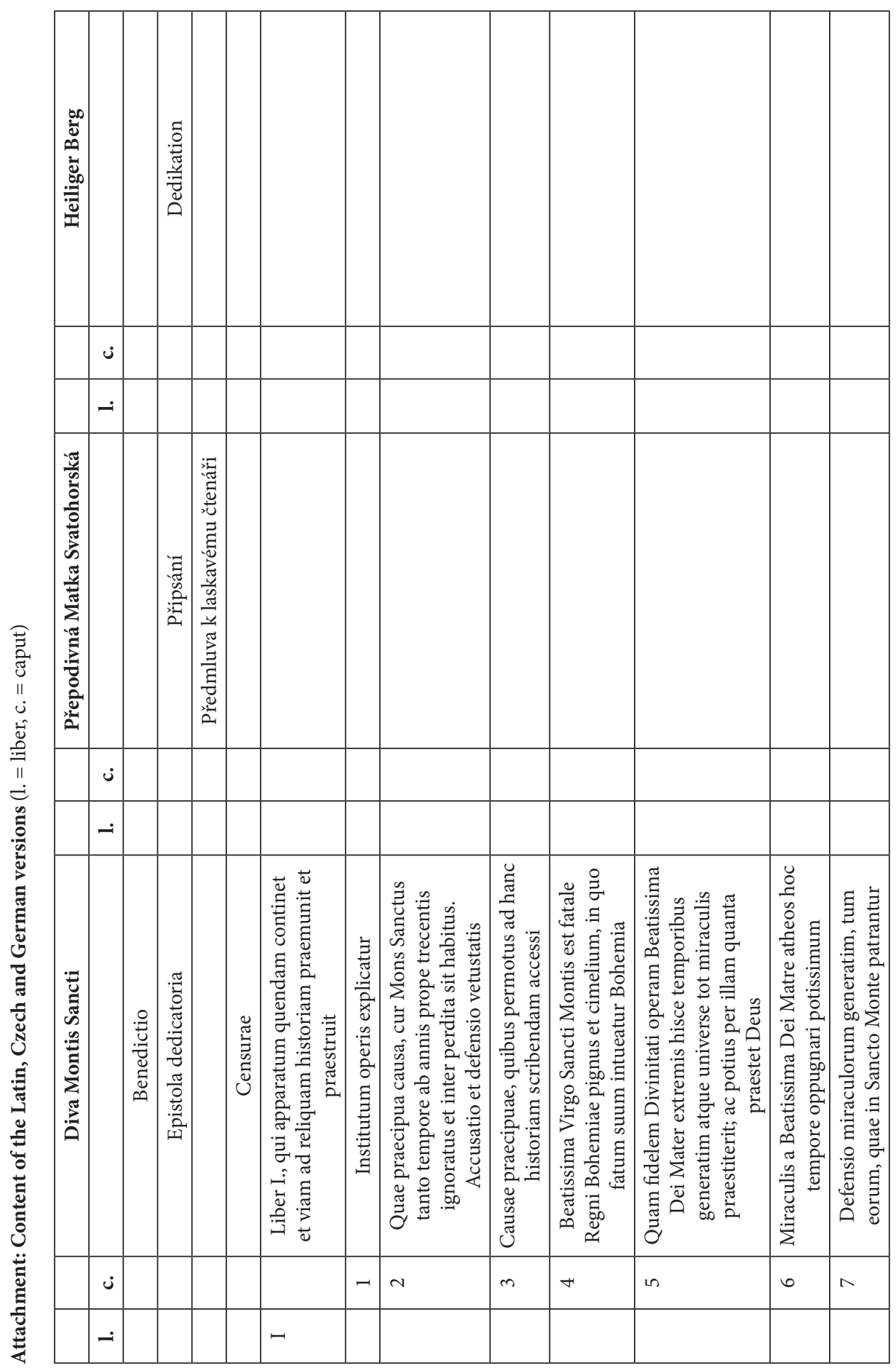




\begin{tabular}{|c|c|c|c|c|c|c|c|c|c|c|c|}
\hline 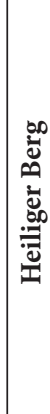 & & & & & & & 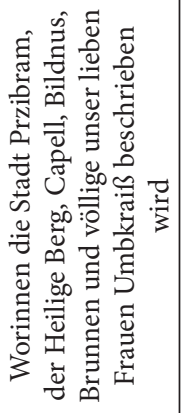 & & 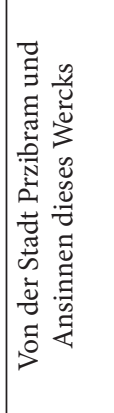 & & \\
\hline & & & & & & & & & - & & \\
\hline & & & & & & & - & & & & \\
\hline 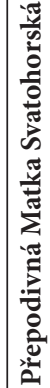 & & & & & & & 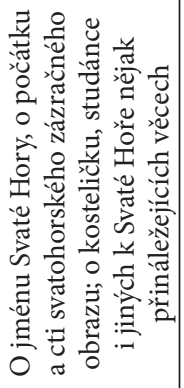 & & & & \\
\hline & & & & & & & - & & & & \\
\hline 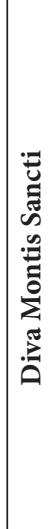 & 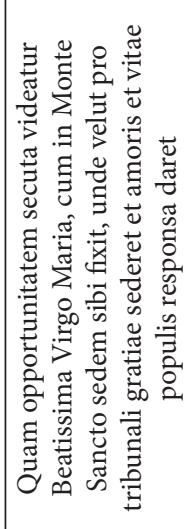 & 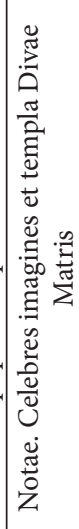 & 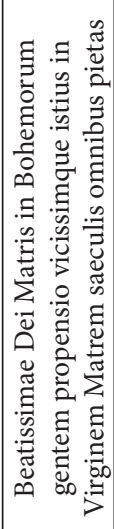 & 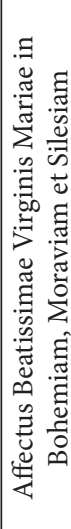 & 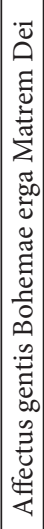 & 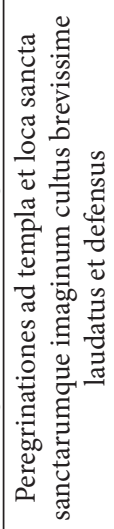 & 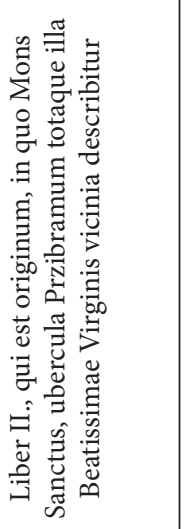 & 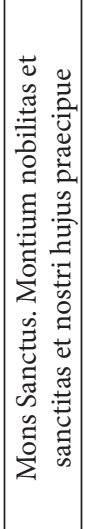 & 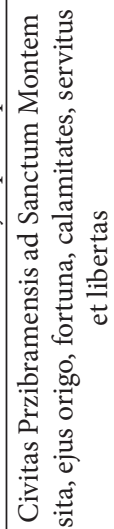 & 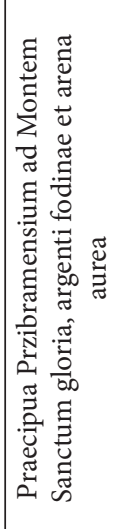 & 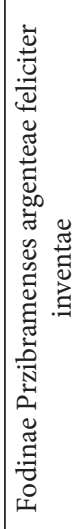 \\
\hline & $\infty$ & & $a$ & $\vec{a}$ & $\approx$ & 으 & & $\neg$ & N & $m$ & $\vec{a}$ \\
\hline & & & & & & & $\exists$ & & & & \\
\hline
\end{tabular}




\begin{tabular}{|c|c|c|c|c|c|c|c|c|c|}
\hline 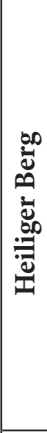 & & & & & & & 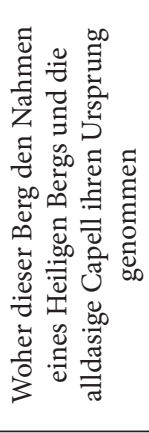 & 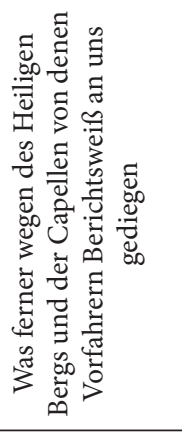 & 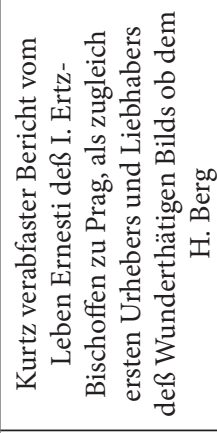 \\
\hline & & & & & & & $N$ & $m$ & 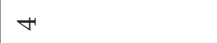 \\
\hline 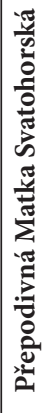 & & & & & 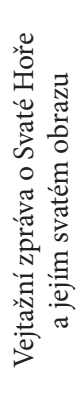 & 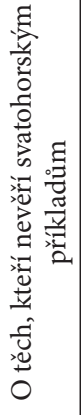 & 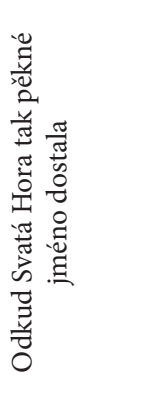 & 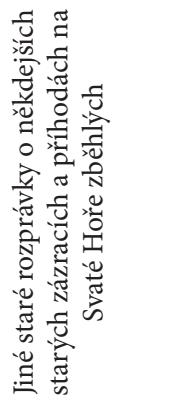 & 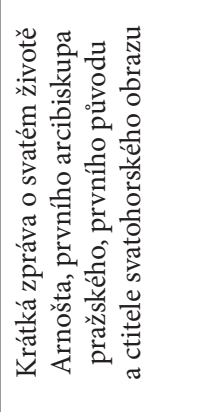 \\
\hline & & & & & - & $\sim$ & $n$ & 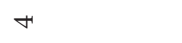 & in \\
\hline 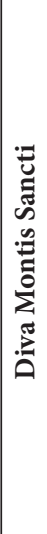 & 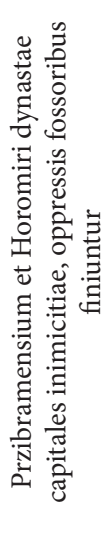 & 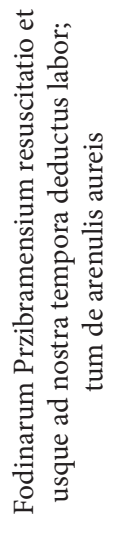 & 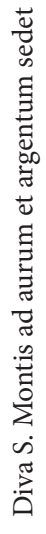 & 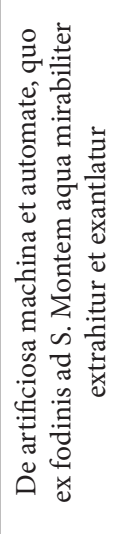 & & & 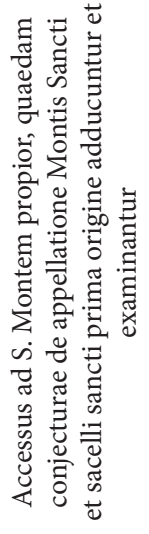 & 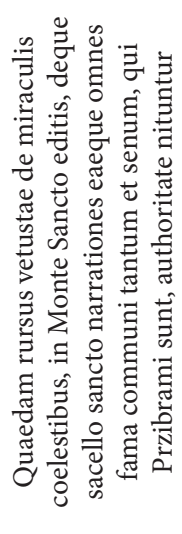 & 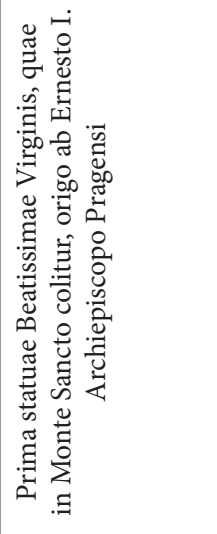 \\
\hline & 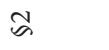 & $\approx$ & 芯 & 2 & & & + & in & 6 \\
\hline & & & & & & & & & \\
\hline
\end{tabular}




\begin{tabular}{|c|c|c|c|c|c|c|c|c|c|c|}
\hline 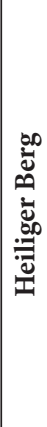 & & & 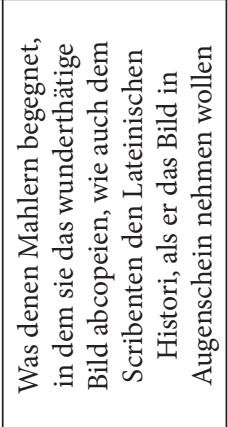 & 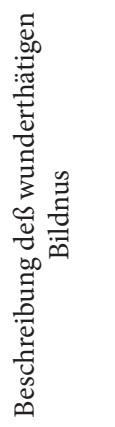 & 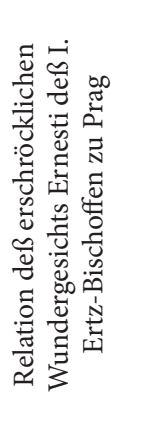 & & 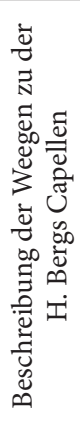 & 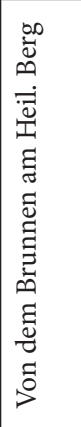 & 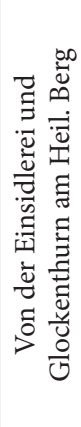 & 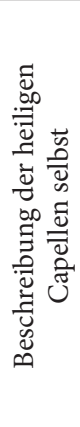 \\
\hline & & & in & 0 & $\curvearrowright$ & & $\infty$ & $a$ & 으 & $\exists$ \\
\hline 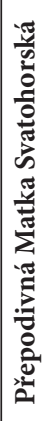 & & & 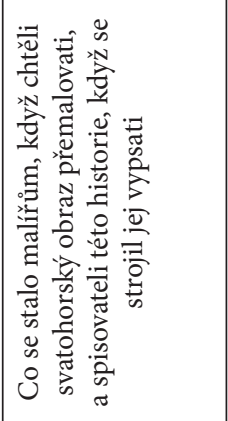 & 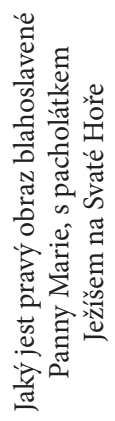 & 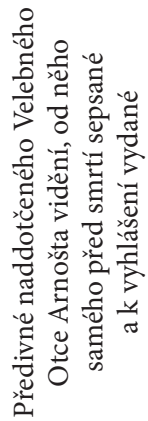 & & 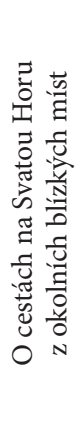 & 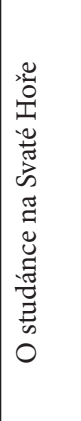 & 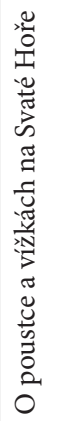 & 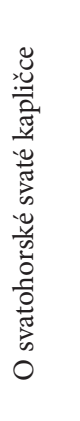 \\
\hline & & & 0 & $\wedge$ & & & $\infty$ & $a$ & 으 & $\exists$ \\
\hline 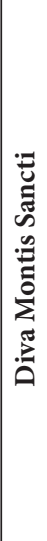 & 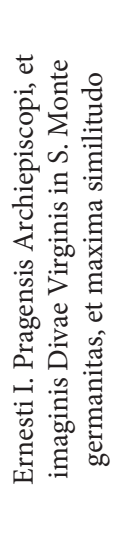 & 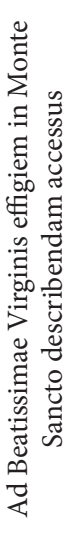 & 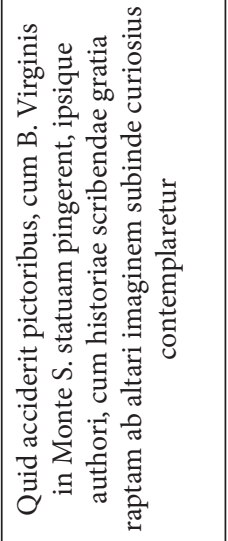 & 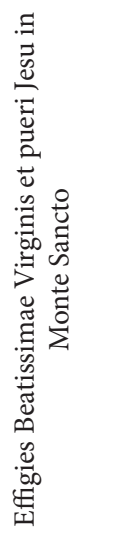 & & 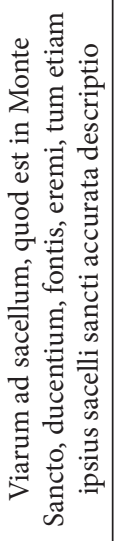 & 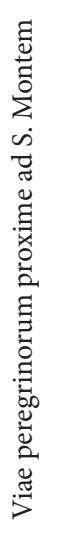 & 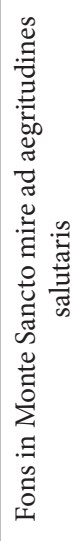 & 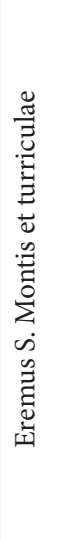 & 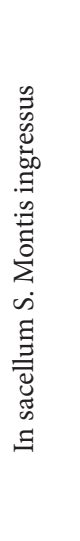 \\
\hline & $\wedge$ & $\infty$ & $\vec{n}$ & $\approx$ & & $a$ & $\vec{a}$ & $\approx$ & $\ddot{n}$ & 苟 \\
\hline & & & & & & & & & & \\
\hline
\end{tabular}




\begin{tabular}{|c|c|c|c|c|c|c|c|c|}
\hline \multirow[t]{2}{*}{ 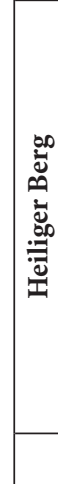 } & 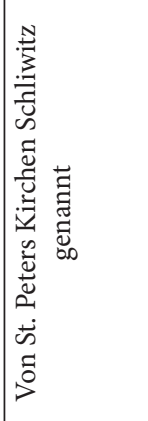 & 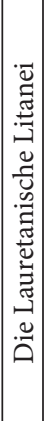 & 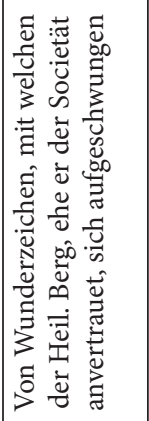 & 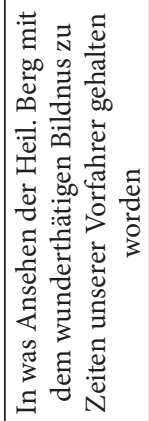 & 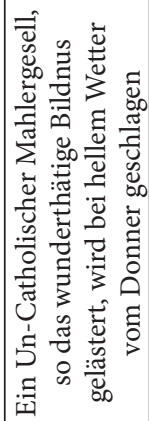 & 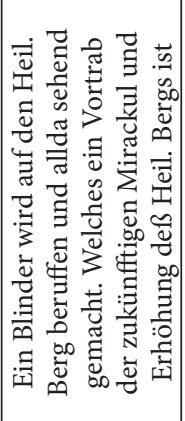 & 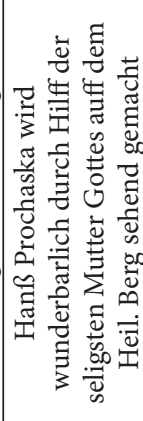 & 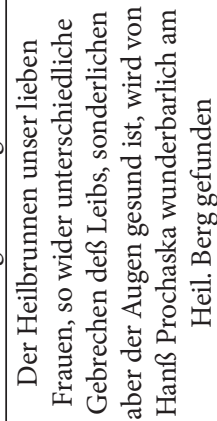 \\
\hline & $\simeq$ & & & - & N & $m$ & $\psi$ & in \\
\hline & & & 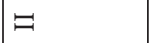 & & & & & \\
\hline \multirow[t]{3}{*}{ 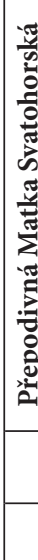 } & 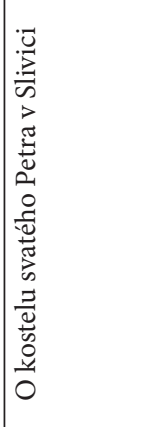 & & 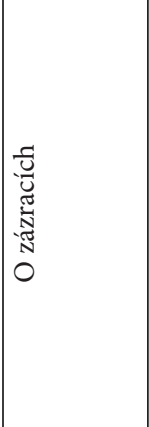 & 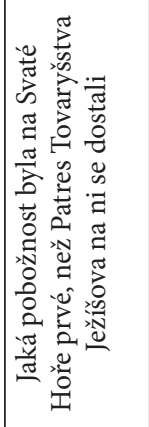 & 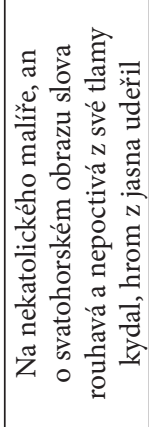 & 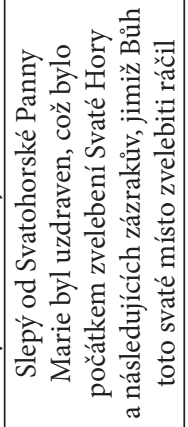 & 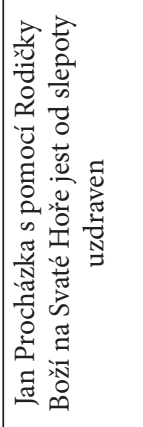 & 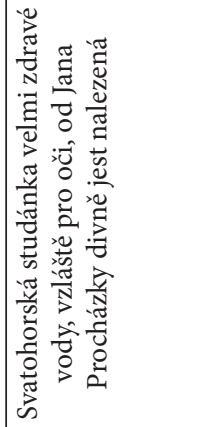 \\
\hline & $\simeq$ & & & - & $\sim$ & $m$ & $\psi$ & in \\
\hline & & & $\exists$ & & & & & \\
\hline \multirow[t]{3}{*}{$\begin{array}{l}0 \\
0 \\
0 \\
0\end{array}$} & 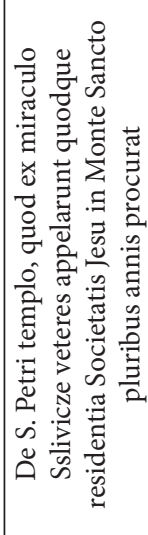 & & 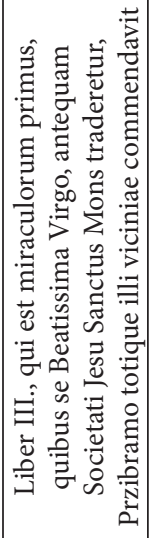 & 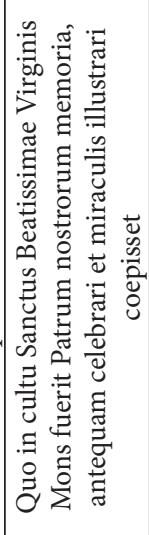 & 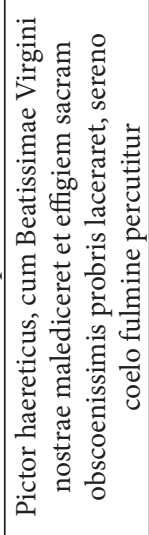 & 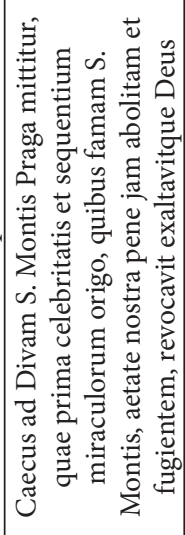 & 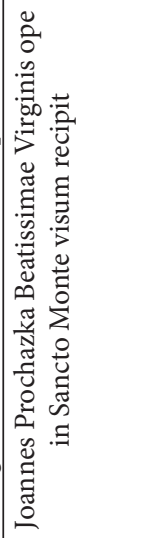 & 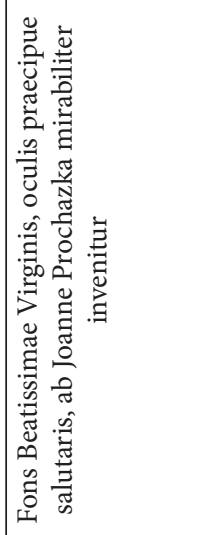 \\
\hline & 으 & & & - & $\sim$ & $m$ & $\psi$ & in \\
\hline & & & $\exists$ & & & & & \\
\hline
\end{tabular}




\begin{tabular}{|c|c|c|c|c|c|c|}
\hline 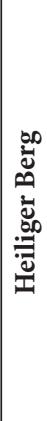 & 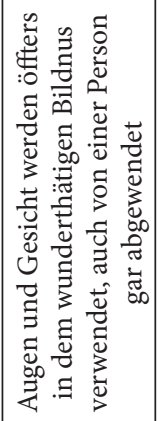 & 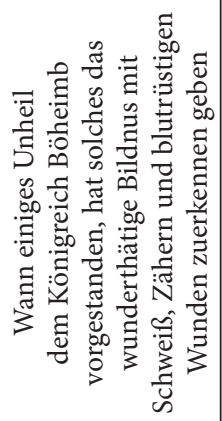 & 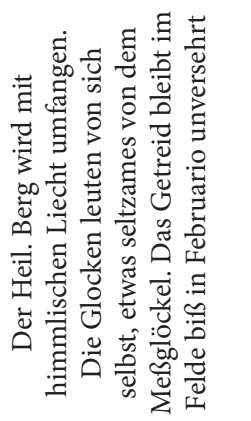 & 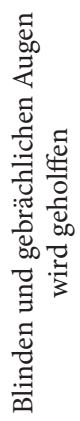 & 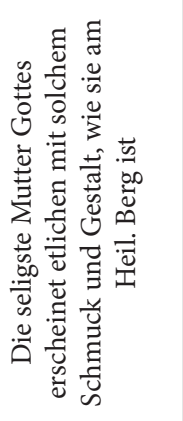 & 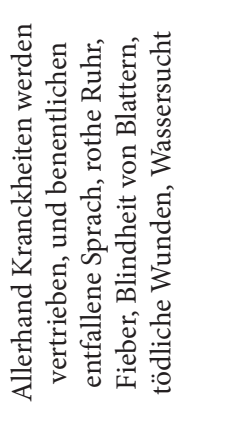 \\
\hline & 0 & $\wedge$ & $\infty$ & $a$ & 으 & $\exists$ \\
\hline 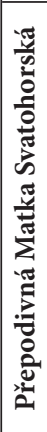 & 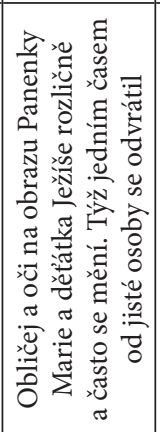 & 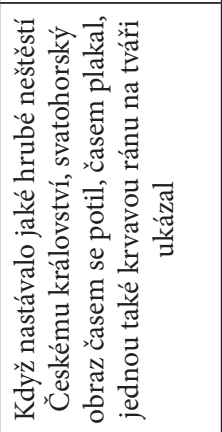 & 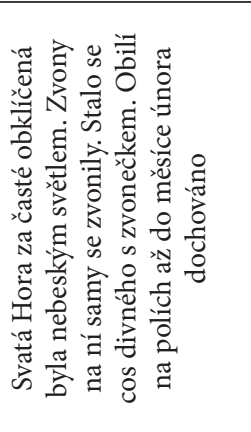 & 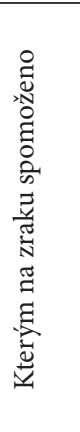 & 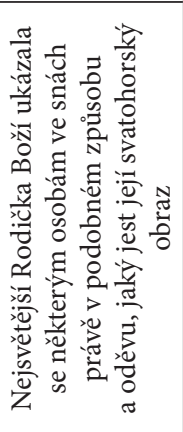 & 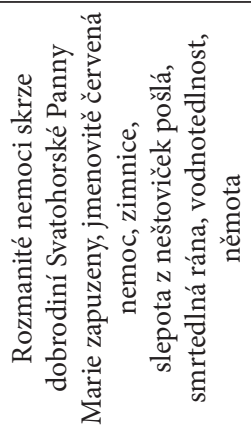 \\
\hline & 6 & $\wedge$ & $\infty$ & $a$ & 으 & $\exists$ \\
\hline 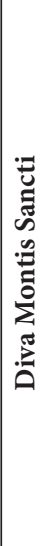 & 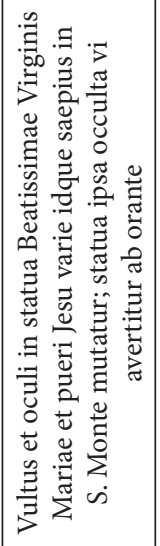 & 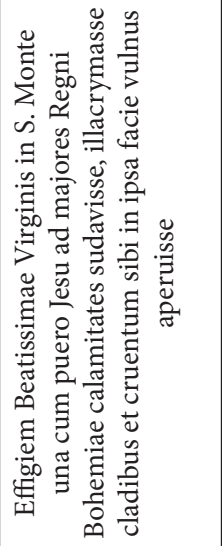 & 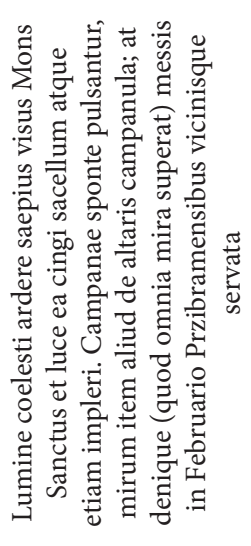 & 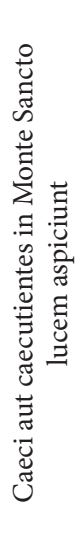 & 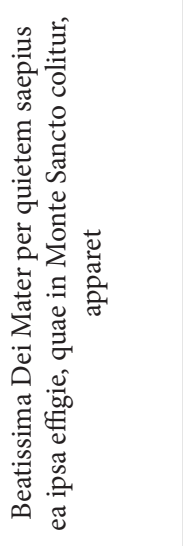 & 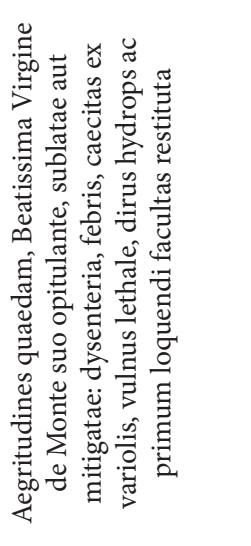 \\
\hline & 0 & $\wedge$ & $\infty$ & $a$ & 으 & $\exists$ \\
\hline & & & & & & \\
\hline
\end{tabular}




\begin{tabular}{|c|c|c|c|c|c|c|c|c|}
\hline 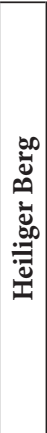 & 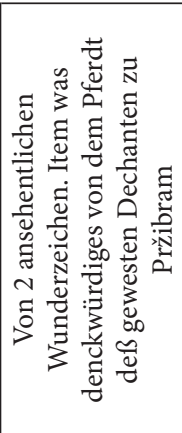 & & 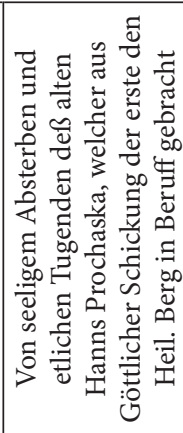 & 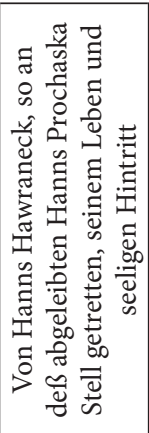 & 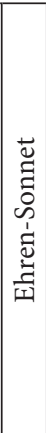 & 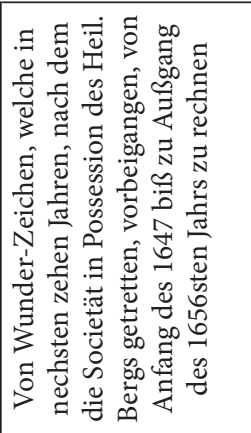 & 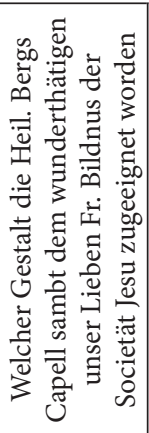 & \\
\hline & $\simeq$ & & $\stackrel{m}{2}$ & 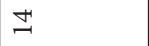 & & & - & \\
\hline & & & & & & ヨ & & \\
\hline 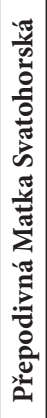 & 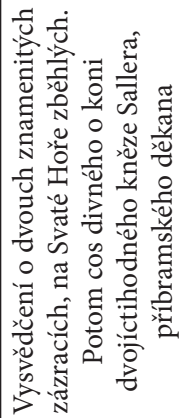 & 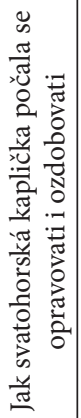 & 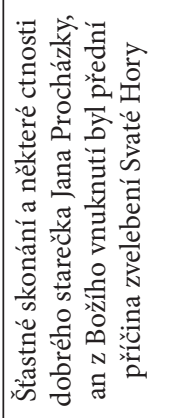 & 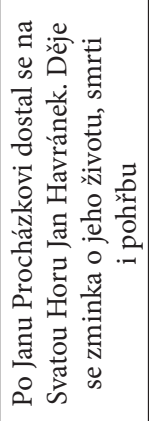 & & 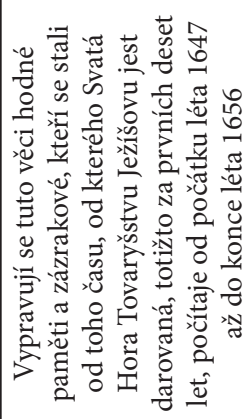 & 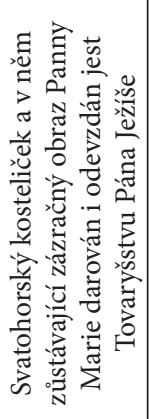 & 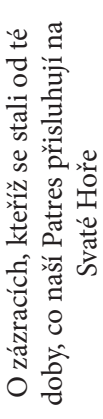 \\
\hline & $\simeq$ & $\stackrel{m}{\sim}$ & $\Xi$ & $\stackrel{20}{\longrightarrow}$ & & & - & $\sim$ \\
\hline & & & & & & $\Xi$ & & \\
\hline 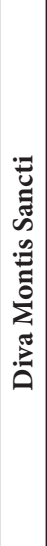 & 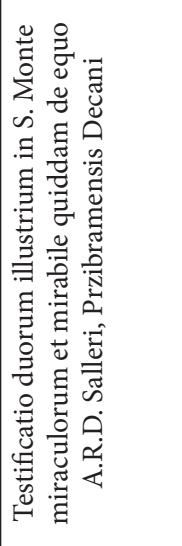 & 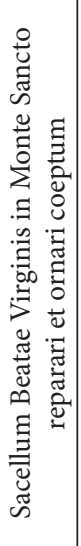 & 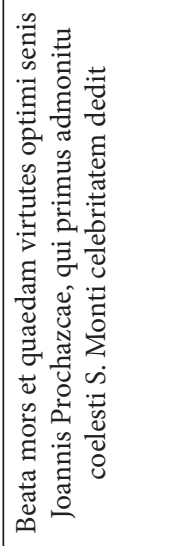 & 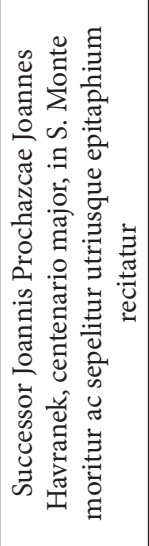 & & 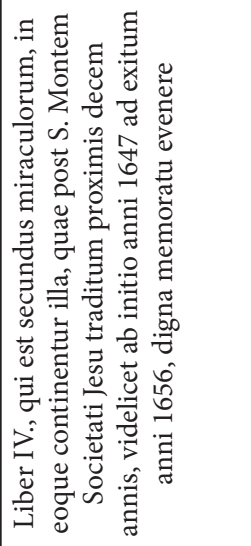 & 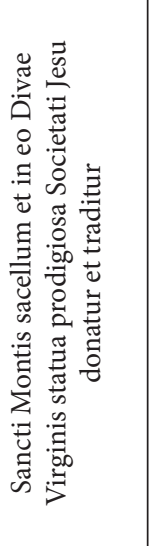 & 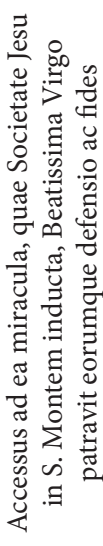 \\
\hline & $\simeq$ & $\stackrel{m}{2}$ & \pm & $\stackrel{10}{\sim}$ & & & $\neg$ & $\sim$ \\
\hline & & & & & & $\geq$ & & \\
\hline
\end{tabular}




\begin{tabular}{|c|c|c|c|c|c|c|c|}
\hline 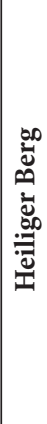 & 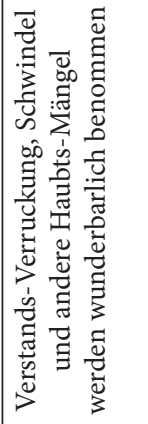 & 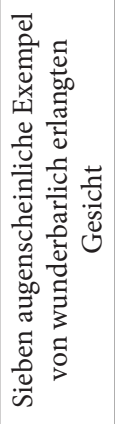 & 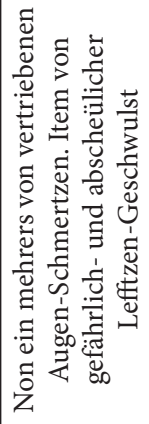 & 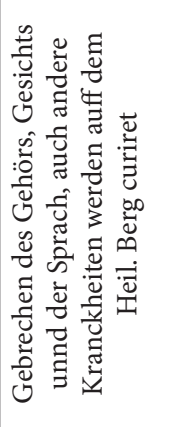 & 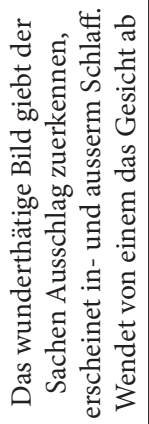 & 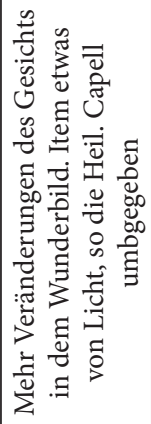 & 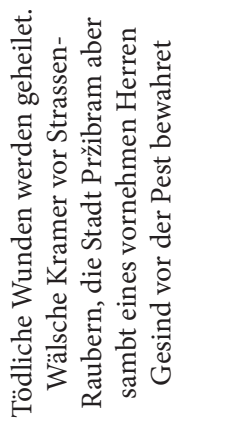 \\
\hline & $\sim$ & $m$ & H & in & 6 & $\wedge$ & $\infty$ \\
\hline 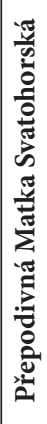 & 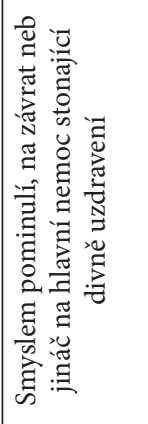 & 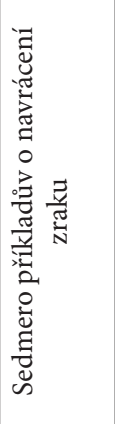 & 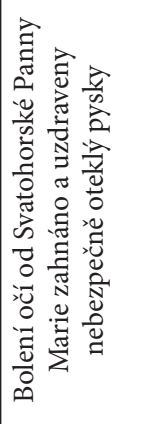 & 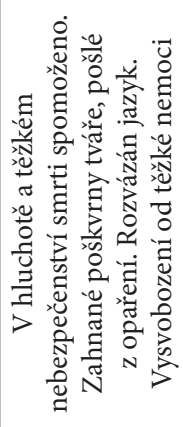 & 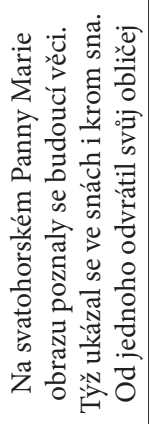 & 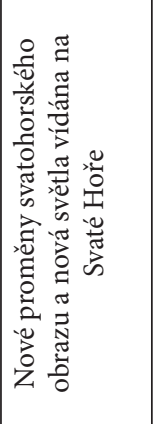 & 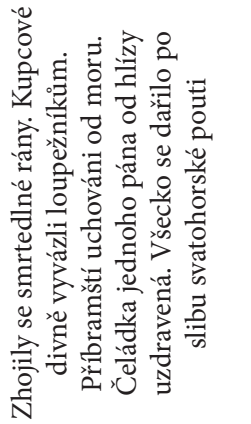 \\
\hline & $m$ & H & in & 6 & $\wedge$ & $\infty$ & $a$ \\
\hline 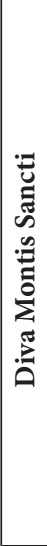 & 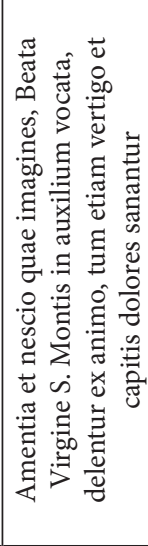 & 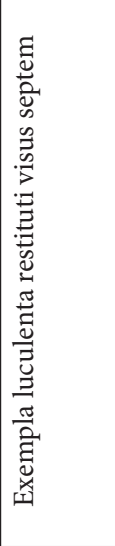 & 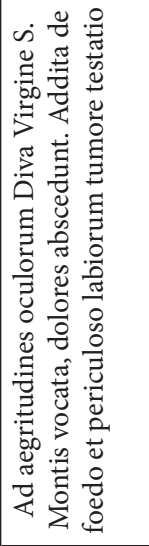 & 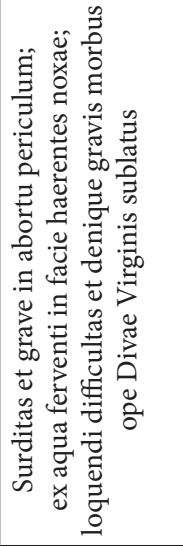 & 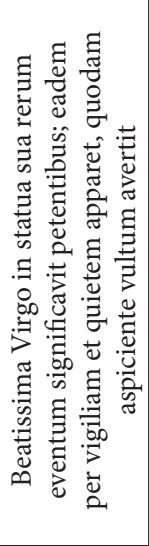 & 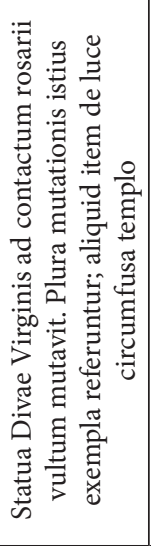 & 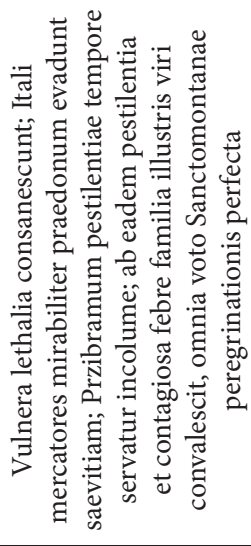 \\
\hline & $m$ & $\theta$ & in & 6 & $\wedge$ & $\infty$ & $a$ \\
\hline & & & & & & & \\
\hline
\end{tabular}




\begin{tabular}{|c|c|c|c|c|c|c|}
\hline 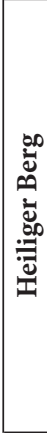 & 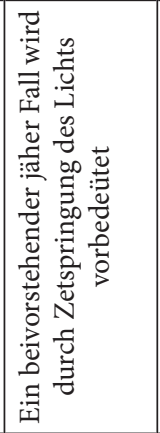 & 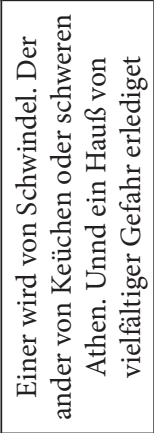 & 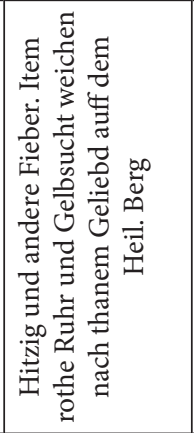 & 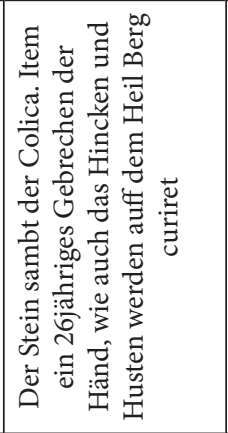 & 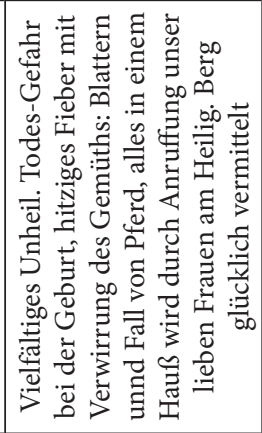 & 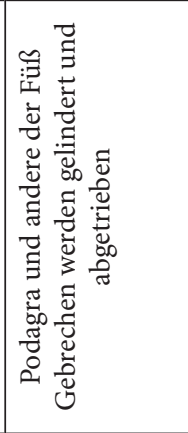 \\
\hline & $a$ & 으 & $\exists$ & $\simeq$ & $\stackrel{m}{n}$ & $\underset{J}{\sharp}$ \\
\hline 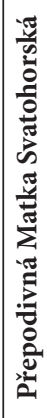 & 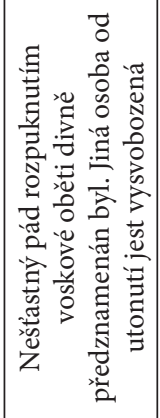 & 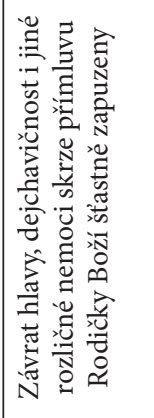 & 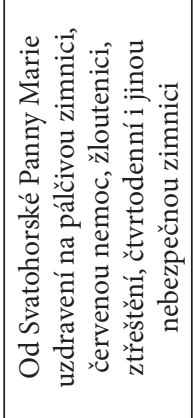 & 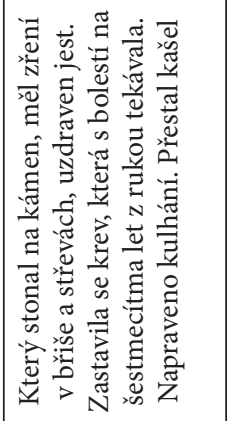 & 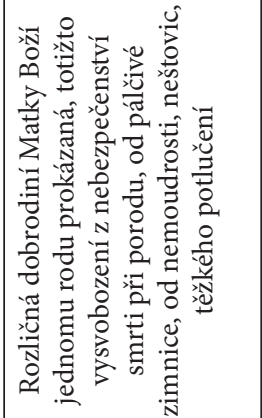 & 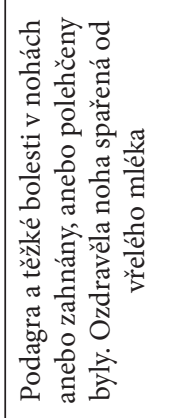 \\
\hline & 으 & $\exists$ & $\simeq$ & $\stackrel{m}{\sim}$ & $\Xi$ & $\stackrel{20}{-1}$ \\
\hline 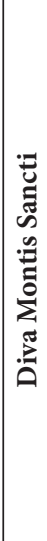 & 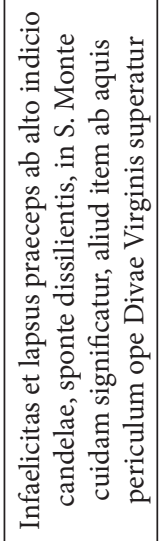 & 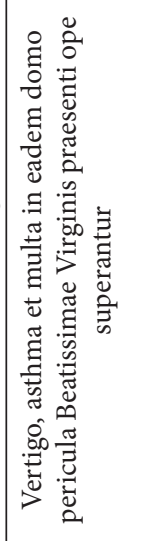 & 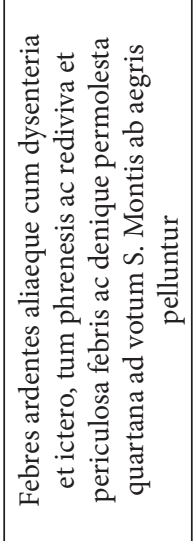 & 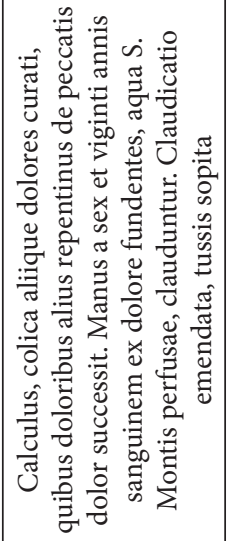 & 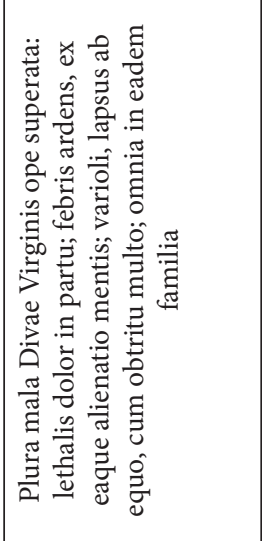 & 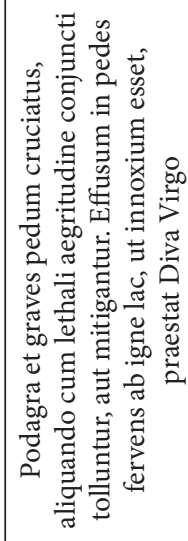 \\
\hline & 으 & $\exists$ & $\simeq$ & 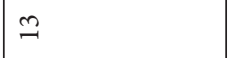 & $\Xi$ & $\stackrel{10}{2}$ \\
\hline & & & & & & \\
\hline
\end{tabular}




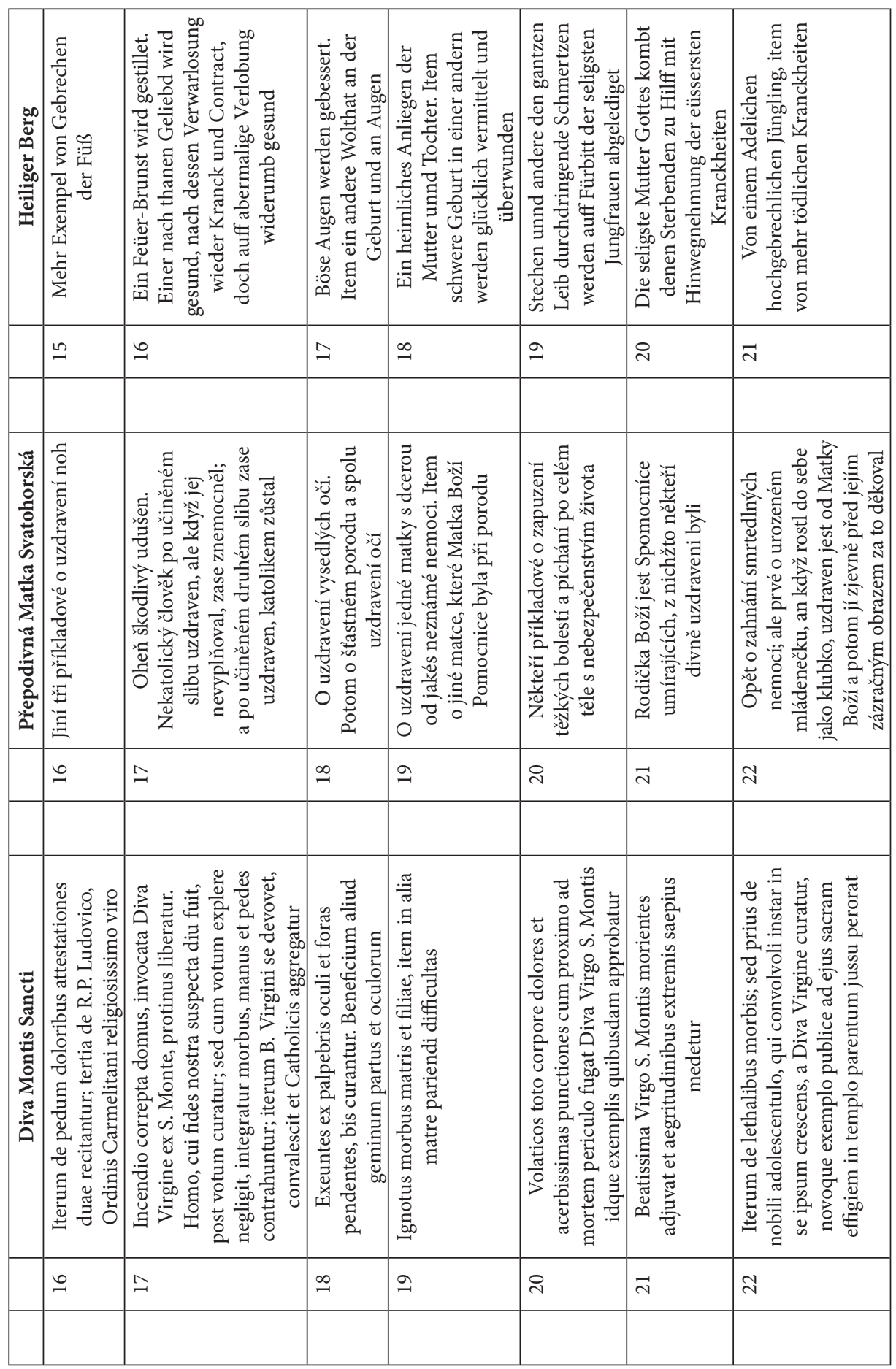




\begin{tabular}{|c|c|c|c|c|c|c|c|}
\hline 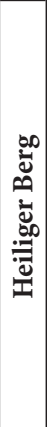 & 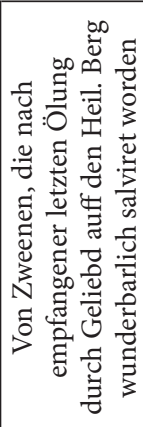 & & & & 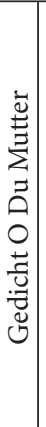 & 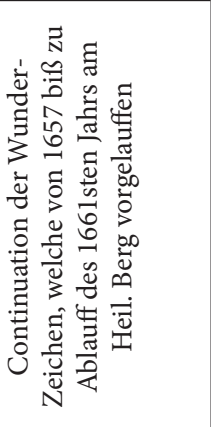 & 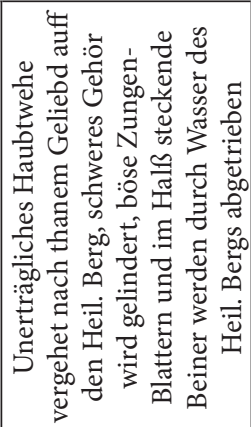 \\
\hline & $\widetilde{N}$ & & & & & & - \\
\hline & & & & & & $\geq$ & \\
\hline 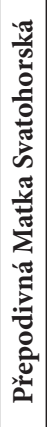 & 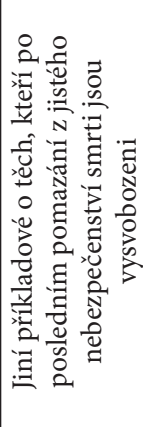 & 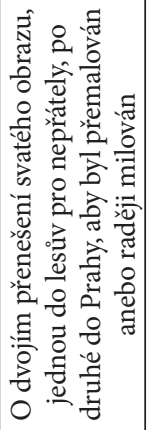 & 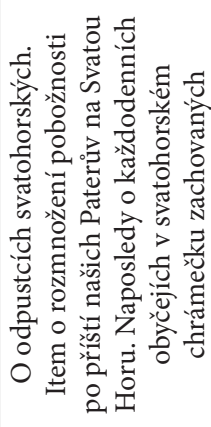 & 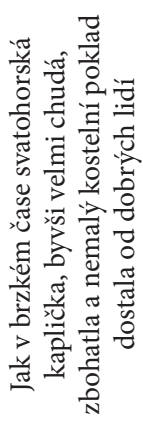 & & 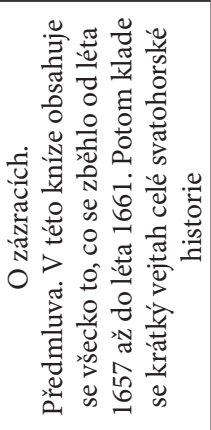 & 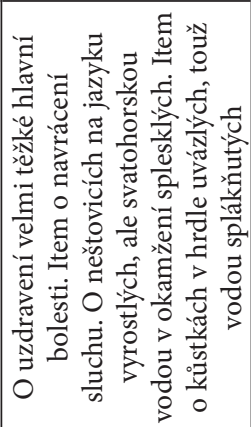 \\
\hline & $\ddot{\sim}$ & $\stackrel{\sim}{\sim}$ & $\stackrel{\Perp}{\sim}$ & $\stackrel{\bullet}{\sim}$ & & & - \\
\hline & & & & & & $\geq$ & \\
\hline 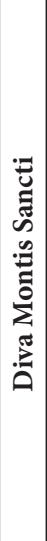 & 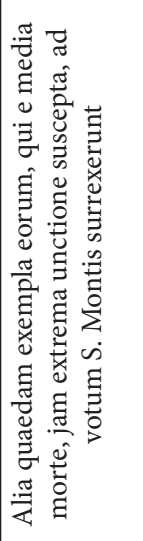 & 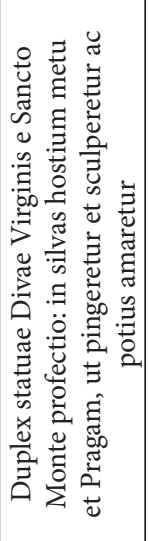 & 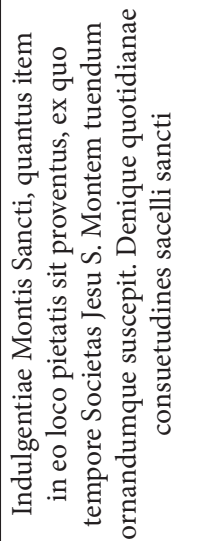 & 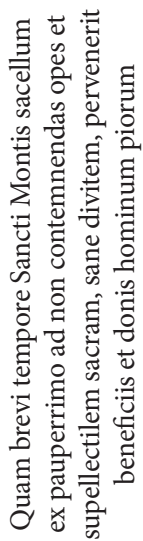 & & 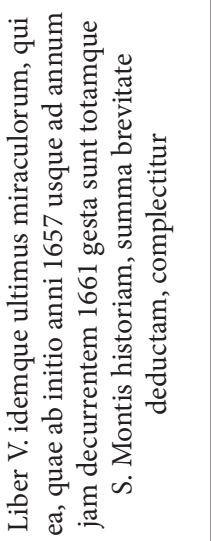 & 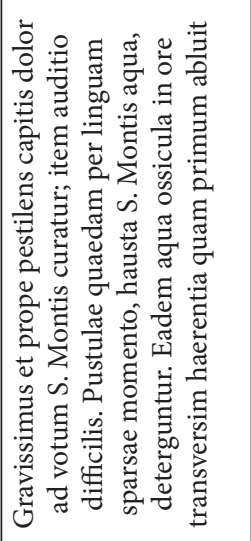 \\
\hline & $\ddot{\sim}$ & $\stackrel{\sim}{\sim}$ & $\stackrel{\mathscr{N}}{\sim}$ & $\stackrel{\imath}{\sim}$ & & & - \\
\hline & & & & & & $>$ & \\
\hline
\end{tabular}




\begin{tabular}{|c|c|c|c|c|c|c|c|c|}
\hline 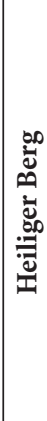 & 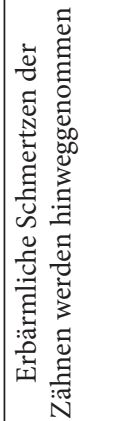 & 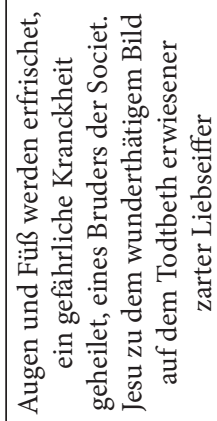 & 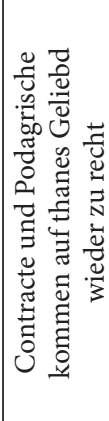 & 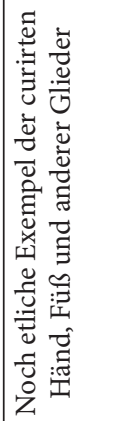 & 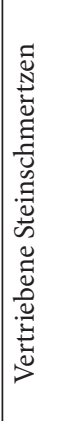 & 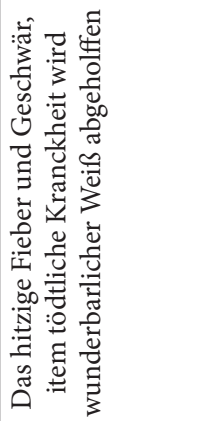 & 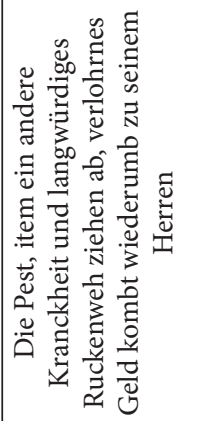 & 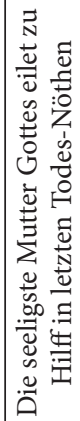 \\
\hline & $\sim$ & $m$ & $\psi$ & in & 0 & 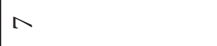 & $\infty$ & $a$ \\
\hline 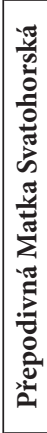 & 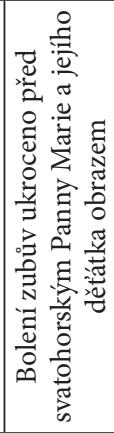 & 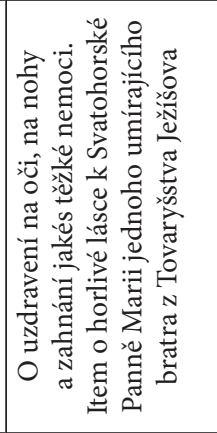 & 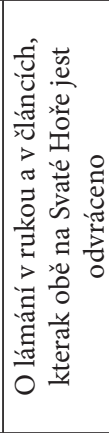 & 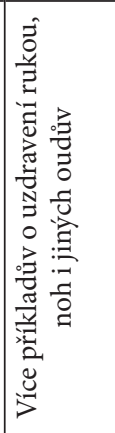 & 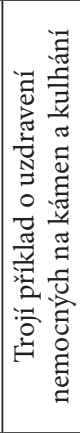 & 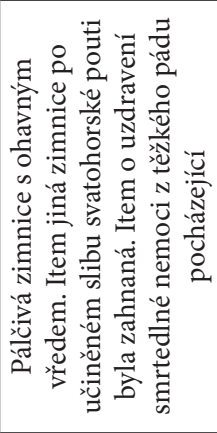 & 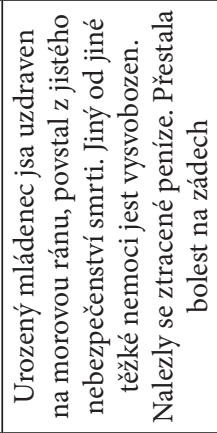 & 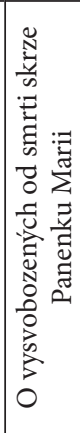 \\
\hline & $\sim$ & $m$ & 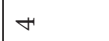 & in & 0 & $n$ & $\infty$ & $a$ \\
\hline 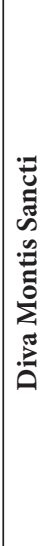 & 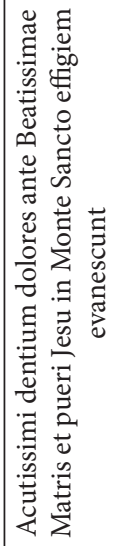 & 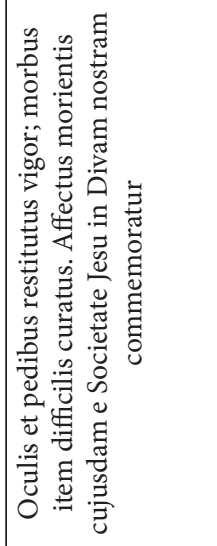 & 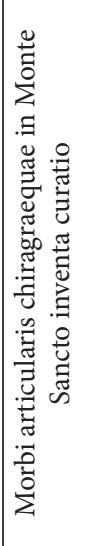 & 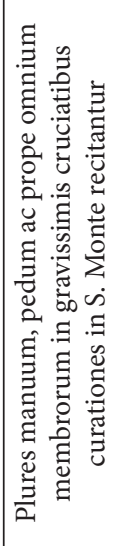 & 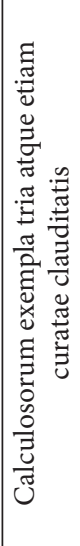 & 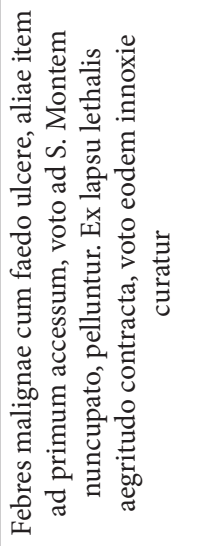 & 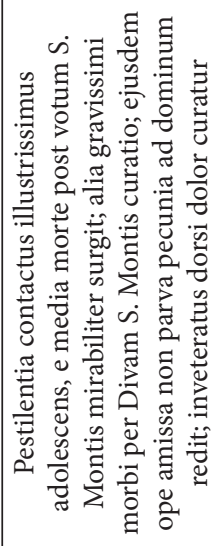 & 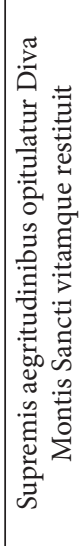 \\
\hline & $\sim$ & $m$ & $H$ & in & 0 & $\wedge$ & $\infty$ & $a$ \\
\hline & & & & & & & & \\
\hline
\end{tabular}




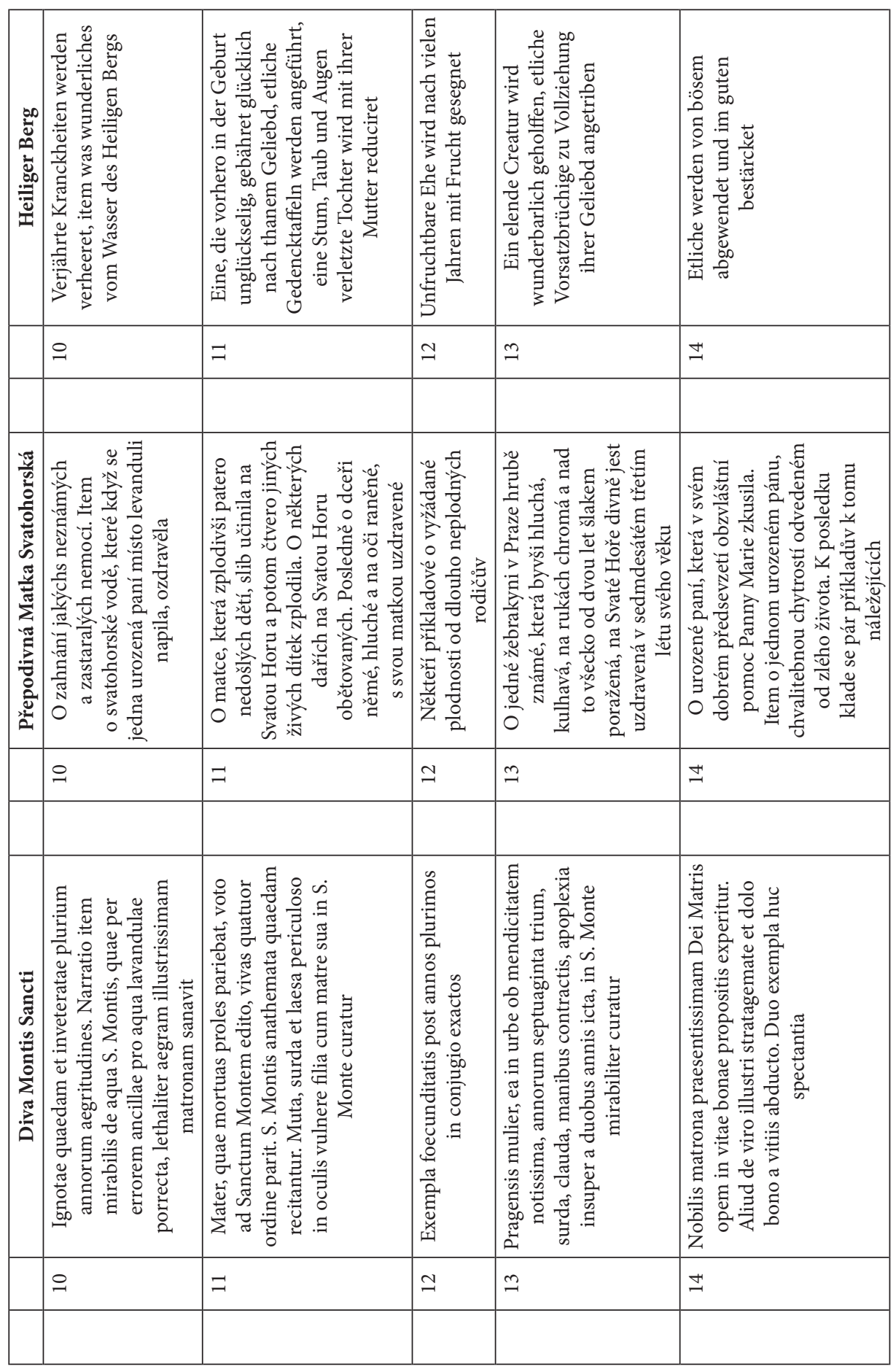




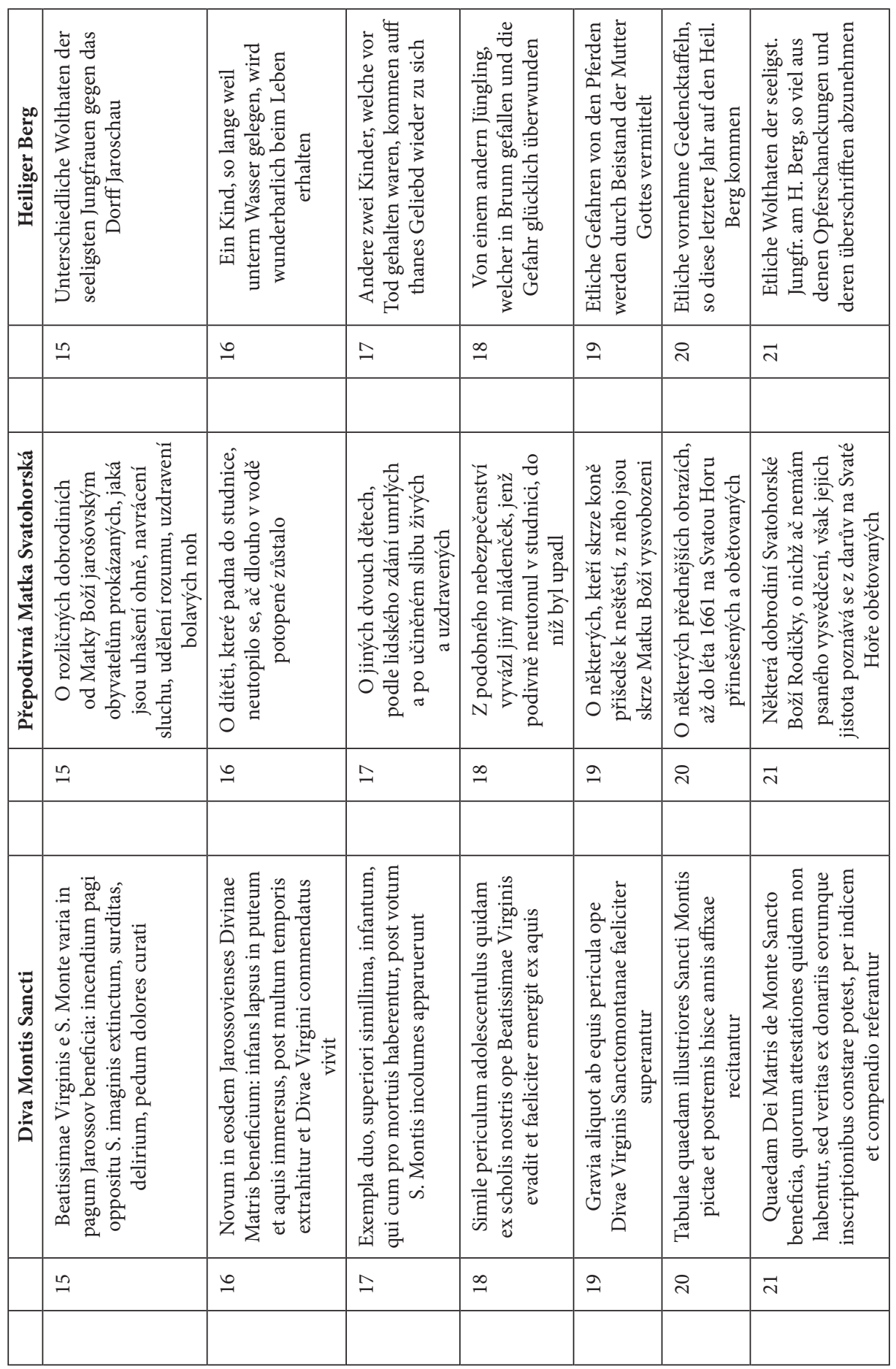




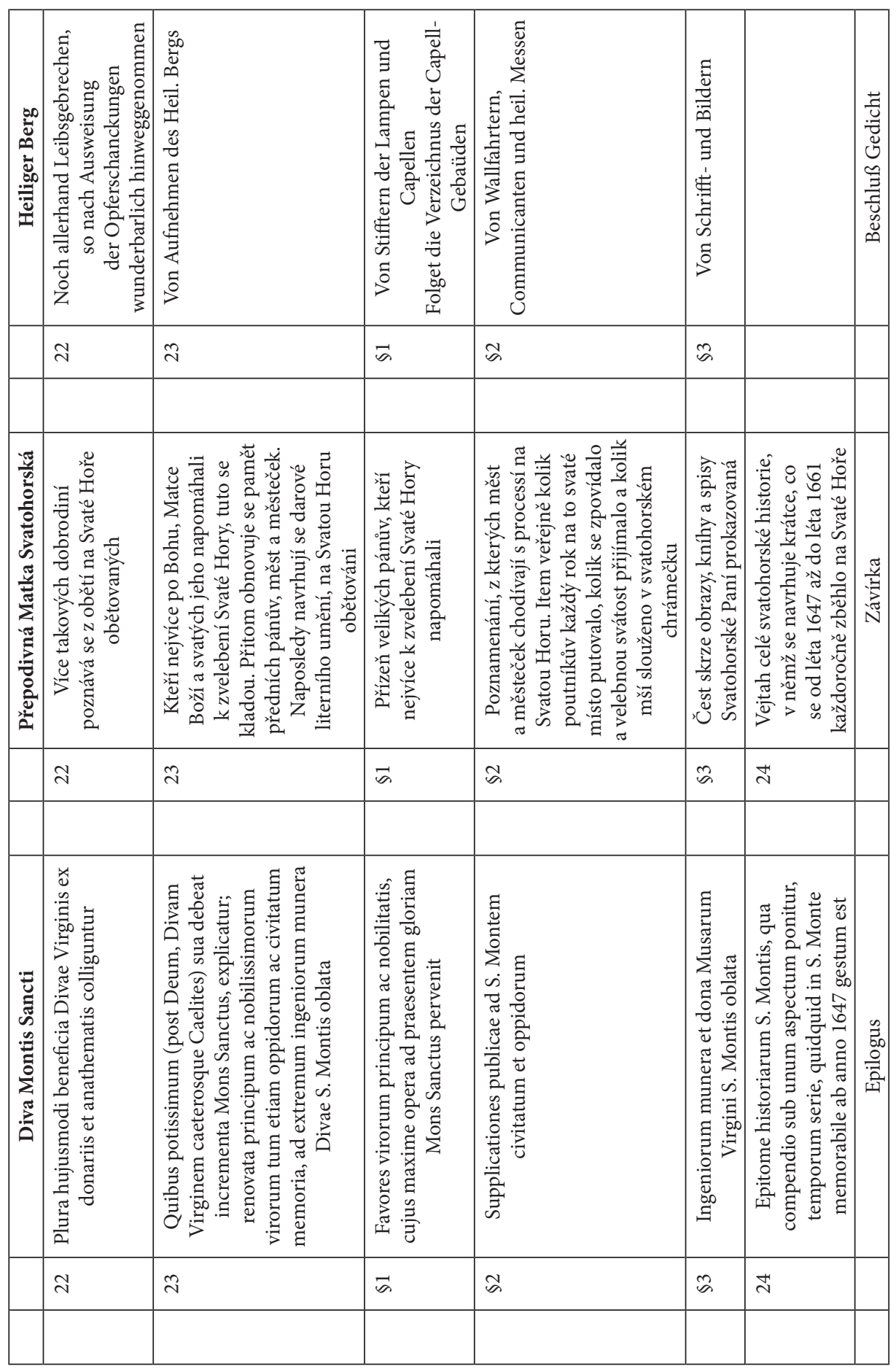




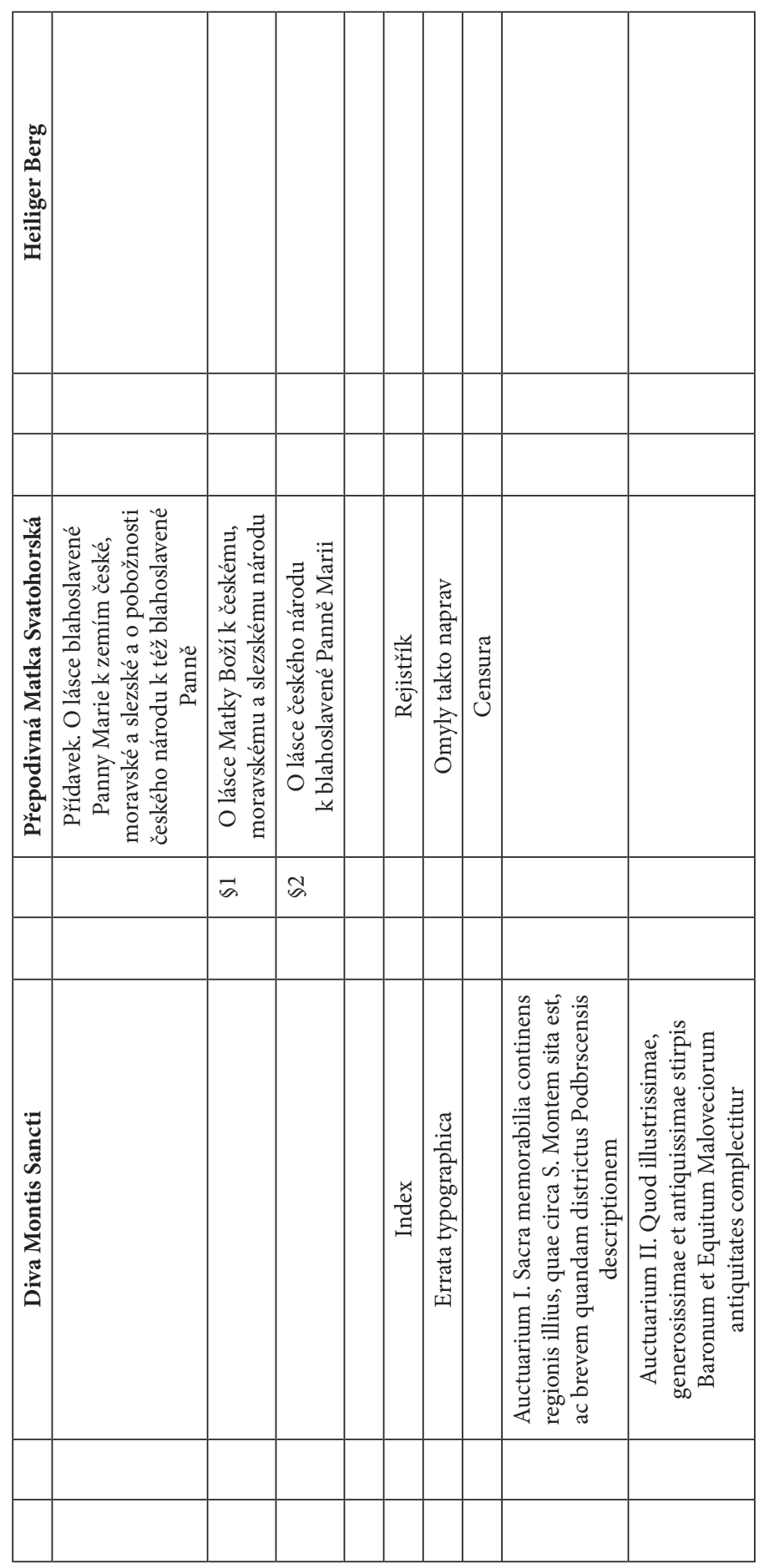

